\title{
Buried pockmarks on the Top Chalk Surface of the Danish North Sea and their potential significance for interpreting palaeocirculation patterns
}

\author{
Samaneh Masoumi ${ }^{1 *}$ Lars Reuning ${ }^{1}$, Stefan Back ${ }^{1}$, Alessandro Sandrin ${ }^{2}$, Peter A. Kukla ${ }^{1}$ \\ $4{ }^{1}$ Geological Institute, RWTH Aachen University, Wüllnerstr. 2, D-52062-Aachen, Germany \\ $5{ }^{2}$ Maersk Oil, Esplanaden 50, 1263 Copenhagen K, Denmark \\ 6 *Corresponding author (e-mail: samaneh.masoumi@emr.rwth-aachen.de)
}

\section{The final publication is available at Springer via http://dx.doi.org/10.1007/s00531-013-0977-2}

\begin{abstract}
Three-dimensional (3D) seismic data from the southern Danish North Sea were used to analyse the morphology and spatial distribution of depressions in the Danian chalk deposit. Previously these depressions were either interpreted as karst structures or pockmarks. The observed depressions occur in an interval from $25 \mathrm{~ms}$ below to 12 ms above the Top Chalk surface. Three types of depressions were differentiated based on their plan view geometry and their degree of symmetry: Type 1, comprising sub-circular and symmetrical depressions, is the dominant group (ca. 70\%). Type 2, elongated and symmetrical depressions, represents only a small fraction (ca. 5\%). The elongated and asymmetrical depressions of Type 3 compose ca. $25 \%$. In cross section, each depression type can be either characterized by a V- or a U-shape. The maximum size of the depressions ranges from $50 \mathrm{~m}$ to $580 \mathrm{~m}$, with an average internal depth of $10 \mathrm{~m}$. We interpret the depressions as pockmarks formed by the expulsion of biogenic or thermogenic fluids at the Danian sea floor. Likely, the initial form of the pockmarks has been circular (Type 1) and was subsequently modified for Type 2 and 3 to an elongated form by currents. The long axis of the pockmarks is interpreted to represent the effective current direction. The inferred direction is subparallel to the palaeobathymetric contours. The 3D seismic interpretation of pockmarks presented in this paper contributes to the understanding of fluid-migration and palaeocirculation patterns during the sedimentation of the terminal Chalk Group in the southern Danish North Sea.
\end{abstract}

Keywords: Top Chalk, Pockmark, Chalk Group, bottom current

\section{Introduction}

The Upper Cretaceous to lower Palaeogene Chalk Group of Northwest Europe represents a period in the Earth's history when a high eustatic sea level, coinciding with a relatively low detrital influx, permitted biogenic sedimentation mainly of pelagic origin on the continental shelves (Hancock, 1975; Kennedy, 1987; Surlyk, 1997; Surlyk et al., 2003; van der Molen et al., 2005; Esmerode et al., 2008). Chalk deposition is classically assumed to represent the settlement of calcarous ooze from suspension, draping pre-existing submarine morphology by a monotonous 'blanket deposit' with mainly parallel bedding relationships and high lateral continuity (for a critical discussion see, e.g. Evans et al., 2003; Surlyk et al., 2008). However, redeposited, less homogeneous chalk sediments have also been identified in the past, mainly in and adjacent to tectonically active areas (e.g. Hardman, 1982; Brewster and Dangerfield, 1984; Hatton, 1986; Bromley and Ekdale, 1987; Cartwright, 1989; Clausen and Huuse, 1999; Evans et al., 2003; Lykke-Andersen and 
Surlyk, 2004; van der Molen et al., 2005). Recently the observation of highly discontinuous reflection patterns on 2D and 3D seismic-reflection data from the NW European Chalk Group initiated a revision of some general ideas about the chalk deposition, proposing that strong oceanic currents and large-scale gravitational processes led to the development of a significant discontinuity within chalk strata (e.g. Lykke-Andersen and Surlyk, 2004; van der Molen et al., 2005; Surlyk and Lykke-Andersen, 2007; Esmerode et al., 2007; Esmerode et al., 2008; Surlyk et al., 2008; Back et al., 2011). The top surface of the Chalk Group, one of the most important unconformities in the North Sea Basin, is characterised as the surface that separates the Upper Cretaceous-Danian Chalk Group from succeeding siliciclastic deposition (Clausen and Huuse, 1999). Morphologic depression features on the Top Chalk surface of the Norwegian-Danish Basin and in the Central Graben were previously identified in $2 \mathrm{D}$ and $3 \mathrm{D}$ seismic data and interpreted alternatively as karst features (e.g. Clausen and Huuse, 1999) or pockmarks (Gemmer et al., 2002). Pockmarks are crater-like depressions on the sea floor often originating from seepage of gas or interstitial liquids (King and MacLean, 1970; Hovland, 1982, 1984; Hovland and Judd, 1988; Van Weering et al., 1997; Judd and Hovland, 2007). Their morphology can be modified by eroding bottom currents (Hovland, 1983, 1984). Andresen et al. (2008) described mid-Oligocene and late Miocene, highly elongated pockmarks in the Danish part of the Central Graben. They interpreted these depressions mainly as a product of fluid expulsion and subsequent erosion by bottom currents. Buried pockmarks hence can be used to reconstruct palaeo-fluid migration pathways (Heggland, 1998; Hovland et al., 2002; Andresen et al., 2008) and a detailed morphologic interpretation of pockmarks allows a reconstruction of bottomcurrent directions. Within this study, more than 170 depressions in an interval immediately below and above the Top Chalk surface in the southeastern Danish Central Graben were mapped from seismic data (Fig. 1). The detailed analysis of their 3D morphology contributes to the understanding of palaeocirculation patterns during the sedimentation of the terminal Chalk Group in the southern Danish North Sea.

\section{Geological setting}

The study area is located in the south of the Danish North Sea Central Graben, which consists of a system of generally NNW-SSE-trending half-grabens bounded by the Coffee-Soil Fault to the east. The study area encompasses the Tyra-Igor and IgorEmma Ridges in the east, the Bo-Jens and Adda Ridges in the north, and the Danish Salt Dome province in the south (Fig. 1). The interval under study is the Chalk Group that spreads over the Central North Sea and extends into the south Viking Graben and onto the east Shetland Platform (Surlyk et al., 2003). It is of Cenomanian to Danian age and is commonly 1-2 km thick in the Graben areas (Japsen 1998; Surlyk et al., 2003; Vejbæk et al., 2007). The sediments mainly consist of pure chalk and limestone, marly chalk, marl and calcareous shale (Hardman, 1982; Surlyk et al., 2003). The Chalk Group can be subdivided into the Hidra, Blodøks, Plenus Marl, Hod, Tor and Ekofisk formations (Fig. 2). The Ekofisk Formation forms the uppermost part of the Chalk Group. It is of earliest Palaeocene (Danian) age and consists of fine-grained, strongly bioturbated chalky limestone with interbedded mudstone (Mortimer, 1987; Surlyk et al., 2003). The top of the Chalk Group forms a prominent seismic marker across the Central North Sea that represents the changeover to siliciclastic sedimentation in the middle Palaeocene (Morton et al., 1993). 
Chalk itself is a cool-water carbonate sediment, consisting predominantly of coccoliths with minor components of foraminifera and calcispheres. During the Late Cretaceous-Early Palaeocene sea-level highstand these sediments were deposited in water-depth of up to several hundred meters within an epeiric sea that flooded most of NW Europe (Gemmer et al., 2002; Surlyk et al., 2003). Chalk deposition was highly dynamic, with large-scale gravity flows and bottom-current activity creating considerable sea-floor morphologies such as channels, drifts and moats (LykkeAndersen and Surlyk, 2004; van der Molen et al., 2005; Surlyk and Lykke-Andersen, 2007; Esmerode et al., 2007; Esmerode et al., 2008; Surlyk et al., 2008; Back et al., 2011; Gennaro et al., 2013). Seismic evidence indicates the presence of contourparallel bottom currents that possibly belonged to a circulation system connecting the Tethyan with the Boreal realm. Fluctuations in the intensity of these currents are thought to be due to eustatic sea-level variations and synsedimentary tectonic movements (Lykke-Andersen and Surlyk, 2004; Surlyk and Lykke-Andersen, 2007; Esmerode et al., 2007).

The deposition of the Chalk Group was greatly influenced by halokinetic movements and fault-controlled subsidence or inversion (Kennedy, 1980; Watts et al., 1980; Hardman, 1982; Brewster and Dangerfield, 1984; Munns, 1985; Hatton, 1986; Bromley and Ekdale, 1987; Barmwell et al., 1999; Farmer and Barkved, 1999; Surlyk et al., 2003). Most of the inversion is believed to have occurred during the deposition of the Chalk Group (Fig. 2), as indicated by the termination of most reverse faults below the top surface of the Chalk Group (Vejbæk and Andersen, 1987). Several inversion events took place during the Late Cretaceous and some minor inversion tectonism occurred more or less continuously between these major events (Vejbæk and Andersen, 1987; Cartwright, 1989). The southern part of the Danish Central Through was mainly affected by inversion during the mid-Maastrichtian and in the early Tertiary after the end of chalk sedimentation (Van Hoorn, 1987; Van Wijhe, 1987). Halokinetic movements started during the Triassic and intrusive activity continued throughout the Late Cretaceous, resulting in the formation of salt pillows, domes, ridges and diapirs (Surlyk et al., 2003).

The Upper Jurassic sedimentary succession of the North Sea (i.e. the Kimmeridge Clay Formation) is the primary source rock for the North Sea, and is in vast areas mature for oil or gas generation (Surlyk et al., 2003; Kubala et al., 2003; Johnson et al., 2005). In the Danish part of the North Sea, the Farsund Formation is the stratigraphic equivalent of the Kimmeridge Clay (Kubala et al., 2003) and covers the entire Danish Central Graben excluding some structural highs (Hemmet , 2005). The Farsund Formation was mature for oil generation at $40 \mathrm{Ma}$ (Eocene) and advanced in this window until $25 \mathrm{Ma}$ (Andresen et al., 2008). In the Miocene the Farsund Formation source rock progressed into the light oil / condensate window, and in Pliocene it started to produce gas (Kubala et al., 2003; Andresen et al., 2008). An additional source rock potential was assigned to the Lola Formation (lower Upper Jurassic), the Lulu Formation (upper Middle Jurassic) and the Middle Jurassic Bryne Formation (Kubala et al., 2003; Petersen et al., 2008) (Fig. 3). The Lola Formation reaches up to $700 \mathrm{~m}$ thickness in the Central North Sea and is late to post-mature for oil generation in the Central Graben (Kubala et al., 2003).

The Middle Jurassic Bryne Formation acts as a source rock for the reservoir rocks of the Upper Cretaceous/Danian (Kubala et al., 2003). The Bryne Formation consists of fluvial deltaic sandstones interbedded with siltstones, mudstones and coals (Hemmet, 2005). The Bryne Formation became mature for oil generation at about $145 \mathrm{Ma}$ and progressed though the oil windows until about $83 \mathrm{Ma}$ (early Cretaceous). 
Since then the Bryne Formation generated light oil / condensate (Fig. 2) until the onset of gas generation during the early Oligocene (Kubala et al., 2003).

\section{Database and Methodology}

The database of this study comprises ca. $2000 \mathrm{~km}^{2}$ of 3D multichannel seismicreflection data processed in zero phase following European polarity convention, i.e. an increase in acoustic impedance is represented by a reflectivity trough. The bin spacing of the 3D seismic survey is $25 \mathrm{~m}$ in inline and crossline directions, and the vertical sampling rate of the data is $4 \mathrm{~ms}$. The strong impedance contrast between the studied Chalk units and the overlying clastic sediments results in a high detectability (visibility sensu Brown, 1999) of a few meters. Further detailed analyses of the most prominent lateral seismic discontinuities in the data were carried out on a Landmark structure attribute volume ( $3 \times 3$ traces and 4 samples). Density, gammaray and velocity well logs from several wells within the study area were used to identify the seismic-reflection response of the Top Chalk surface (seismic-to-well tie: Fig. 4).

Circular to elongate morphological depressions on the seismic data of the Top Chalk surface were interpreted in detail using seismic cross-sections and horizon slices. Based on their ellipticity the depressions were classified in two end-member categories, 1) sub-circular and 2) elongate. This subdivision is based on the ellipticity index (length of long axis / length of short axis). The sub-circular depressions have an ellipticity index $<1.1$. A higher ellipticity index characterises elongate depressions. The degree of symmetry and their cross-sectional geometries (U- or V-shaped) were evaluated qualitatively from vertically exaggerated seismic profiles. The respective lengths of the long and short axes were measured on structural attribute map displays. The direction of the long axes was used to calculate the orientation of the high elongate depressions. The depth of the depressions was measured on seismic cross sections as vertical distance between the deepest point and a straight line connecting the flanks of the depressions. Finally the TWT measurements were converted to meters by using well-velocities.

\section{Results}

This study focuses on the top of the Chalk Group as key interpretation target. This surface (Top Chalk) is interpreted to have formed at the end of the Danian when first siliciclastic sediments were introduced to the basin (Surlyk et al., 2003). Density and gamma ray logs were used to identify the seismic expression of this lithological change (e.g. Fig. 4). The Chalk Group deposits are characterized by generally low gamma-ray values that can increase slightly towards the top of the Chalk Group. The lithologic boundary to the post-Danian siliciclastics is marked by a rapid shift to high gamma-ray values. Density logs in the Chalk Group commonly show a progressive upward decrease with relatively low values within the terminal Chalk unit. Sonic logs are marked at Top Chalk level by a rapid upward increase in the interval transit-time (decrease in velocity). This velocity change commonly coincides with a trough in reflectivity on seismic cross-sections that was used for the interpretation of the Top Chalk surface (Fig. 4, well 1). In gas-affected areas, where the continuity and amplitude of the reflection peak was reduced or a polarity reversal was encountered (Fig. 4, well 2), gamma-ray logs were used to identify the Top Chalk surface. 
The structure-attribute map generated for the Top Chalk surface (Fig. 5) shows clusters of isolated depressions. About 20 depression features can be found in the southwest of the Tyra-Igor Ridge (Fig. 5, Area 1). A total of 140 depression features were identified around the Skjold salt-diapir. These depressions are distributed on the northwestern, southwestern and southeastern flanks of the Skjold salt-diapir (Fig. 5, Area 2). About 10 depressions were found on the southwestern flank of the Dan salt structure (Fig. 5, Area 3).

All depressions appear concurrently within an interval from about 25 ms TWT below to about 12 ms TWT above the Top Chalk surface (Fig. 6).

In plan view the shape of the depressions varies from sub-circular to elongate (Figs. 7,8 and $9 \mathrm{a}$ ). The degree of symmetry was evaluated for all depressions based on the position of their deepest point on cross sections. Elongate depressions were classified as symmetrical or asymmetrical, if their deepest point was located on or off the middle of their long axis respectively. The deepest point of sub-circular depressions is always located in their centre (Figs. 7 and 8). On vertical crosssections, the depressions are usually characterized by well-defined, smooth basal reflectors (Fig. 7); however in exceptional cases the depressions can show a rough, irregular and wavy base. The depressions do not show any internal reflector due to the limited seismic resolution or a homogenous infill with no internal stratification. The geometry of the depressions varies gradually (Fig. 9), but based on their geometry in plan view and their degree of symmetry, three different end-member types could be defined. Additionally, each of these depression types can either have a V-or a Ushape in cross section (Figs. 7 and 8).

Depression Type 1 comprising sub-circular and symmetrical depressions is the most abundant group (68\%) of depression in the study area. Within this group, U-shaped cross sections are only slightly more common (52\%) than V-shaped ones (48\%). Depression Type 2, elongate and symmetrical depressions, form only a small fraction $(6 \%)$. Of this type, $62 \%$ are characterized by a U-shape. Type 3 , elongate and asymmetric depressions, form $26 \%$ of all depressions. U-shaped cross-section predominate (82\%) this group (Fig. 8).

In the Skjold area, the diameters of Type 1 depressions range from $50 \mathrm{~m}$ to $460 \mathrm{~m}$, with an average of $\sim 160 \mathrm{~m}$. The length of the short axis of Type 2 and 3 depressions varies between $70 \mathrm{~m}$ and $400 \mathrm{~m}$, with a significantly $(\mathrm{p}<0.05)$ but only somewhat higher average of $\sim 200 \mathrm{~m}$ (Fig. 9). The length of the long axis of Type 2 and 3 is larger than the diameter of Type 1 ranging from $110 \mathrm{~m}$ to $580 \mathrm{~m}$, with a significantly $(p<0.05)$ larger mean of $\sim 280 \mathrm{~m}$ (Fig. 9). The ellipticity index of Type 2 and 3 depressions ranges from 1.1 to 2.7 , with a mean of around 1.5 (Fig. 9). The long axes of depression Type 2 and 3 depressions are oriented either SE-NW $\left(140^{\circ}-160^{\circ}\right.$, $74 \%)$ or E-W $\left(90^{\circ}-100^{\circ}, 26 \%\right.$; Fig. 9).

The deepest point within the SE-NW (E-W) oriented depressions of Type 3 is located towards the SE or $E$ with respect to their centre. The sub-circular depressions of Type 1 are located near the salt-diapir in the Skjold area. Most of the elongate ones of Type 2 and 3 with U-shaped are placed further away from the salt-diapir (Fig. 10). The depth of the Skjold area depressions is about $10 \mathrm{~m}$ for all three types.

All depressions of the Tyra area belong to Type 1 and are characterized by U-shaped cross sections. They are significantly $(p<0.05)$ smaller if compared to the other areas, with a diameter ranging from $60 \mathrm{~m}$ to $155 \mathrm{~m}$ and a mean of around $120 \mathrm{~m}$. The average depth of the Tyra depressions is ca. $10 \mathrm{~m}$. All depressions close to the Dan salt structure belong to Type 3 and are characterized by U-shaped cross sections. The length of their long axes varies from $125 \mathrm{~m}$ to $270 \mathrm{~m}$, with an average of $180 \mathrm{~m}$ (Fig. 9). The length of their short axes varies from $70 \mathrm{~m}$ to $190 \mathrm{~m}$, with an average of 
$120 \mathrm{~m}$ (Fig. 9). Their ellipticity index ranges from 1.3 to 2 (Fig. 9). Their mean ellipticity index of around 1.6 is not significantly different $(p>0,05)$ from Type 2 and 3 depressions in the Skjold area. All long axes of the depressions are oriented SE-NW $\left(150^{\circ}-160^{\circ}\right.$, Fig. 9). Their deepest point is located towards the SE with respect to their centre, and the depth of the depressions is also around $10 \mathrm{~m}$.

\section{Discussion}

Previously, depression features at Top Chalk level in the Norwegian-Danish Basin and the Danish Central Graben were interpreted as pockmarks (Gemmer et al., 2002) or karst phenomena (Clausen and Huuse, 1999; Huuse, 2001), since both processes are able to generate sub-circular structures visible on 3D seismic data (Stewart, 1999; Rosleff-Soerensen et al., 2012). Geodynamic modelling of the MidPalaeocene palaeogeography by Gemmer et al. (2002) indicated palaeo-water depths of several hundred meters in the southeastern Danish Central Graben. Therefore Gemmer et al. (2002) ruled out karst related to subaerial exposure as a possible explanation for the formation of the depressions. However, subsurface hypogenic karstification can create very similar morphologies to subaerial epi-karst and can occur independently of the palaeogeographical setting. Hypogenic karst is characterized by dissolution, where aggressive fluids are continuously delivered to the dissolution front (Palmer, 1991; Tóth, 1999) often in the vicinity of fault and fracture systems overlain by impermeable facies (Immenhauser et al., 2007). In the Tyra area, the depressions are located in close proximity to a major fault system. This fault seems to have been an active fluid pathway since at least Eocene times (Fehmers et al., 2012). In the Skjold and Dan areas, however, horizon-slice data in structure attribute display show no direct connection between the observed depression features and seismically resolved faults (Fig. 11). If aggressive fluids ascending along fault or fracture networks would be responsible for depression formation, we would expect these to be clustered along lineaments. In contrast, we observe isolated depressions that do not show a linear arrangement (see Fig. 5). The apparent lack of a direct link between faults and depressions therefore likely contradicts an interpretation as hypogenic karst around the Skjold and Dan structures. Thus, based on their palaeobathymetric setting and distribution within the study area and a morphological comparison with similar features described in the literature (Hovland, 1982; Prior et al., 1989; Fader, 1991; Kelley et al., 1994; Bizarro, 1998; Bøe et al., 1998; Heggland, 1998; Huuse, 1999; Stewart, 1999; Cole et al., 2000; Gemmer et al., 2002; Hovland et al., 2002; Çifçi et al., 2003; Ussler et al., 2003; Sumida et al., 2004; Hovland et al., 2005; Gay et al., 2006; Andresen et al., 2008; León et al., 2010) the mapped depressions are here interpreted as palaeopockmarks.

High seismic amplitudes in the centre of the pockmarks are often interpreted either as accumulation of coarse sediments by gas winnowing or as authigenic carbonate precipitates (Hovland et al., 2002; Andresen et al., 2008). The absence of such reflection anomalies in this study (Fig. 12) might instead point to short lived expulsion events, preventing the precipitation of diagenetic cements that are typical for systems active over long time periods (Andresen et al., 2008). Violent fluid escape and rapid pockmark formation takes place when a seal close to the seafloor is breached by accumulating fluids and the associated pressure build-up (Judd and Hovland, 2007; Hovland et al., 2010). Betzler et al. (2011) point out that fine-grained carbonate sediments in basinal settings could provide a capillary seal (sensu Cathles et al., 
2010). Such a capillary seal would allow the formation of pressurised gas pockets close to the seafloor in the fine-grained carbonates of the Ekofisk Formation.

Seepage of gas, oil, brine and hydrothermal fluids (Hovland and Judd, 1988; Judd and Hovland, 2007) can generate pockmarks. Some pockmarks are interpreted to have formed by gas hydrate dissociation (Bünz et al., 2003; Gay et al., 2006), but relatively high-pressures and low-temperature are necessary for the formation of gas hydrates. The water-depth within the southeastern Central Graben was estimated to be 250-600 m during the Mid-Palaeocene (Gemmer et al., 2002), and the climate was warm. Thus, the pressure and climate conditions were not favourable for the generation of gas hydrates.

Biogenic gas can form within organic rich sediments during shallow burial (Hovland and Judd 1988). The Quaternary sediments of the Great Australian Bight are lithologically similar to the Upper Cretaceous-Danian limestone of the North Sea (cf. Surlyk, 1997). Large concentrations of biogenic methane and hydrogen sulfide were discovered in the shallow subsurface of the Great Australian Bight (Swart et al., 2000). In analogy it seems thus possible that biogenic gas might have been produced from Late Cretaceous and early Palaeocene coccolith ooze that could have led to pockmark creation at the Top Chalk surface (Huuse et al., 2001). Alternatively, thermogenic fluid/gas could have been provided by the maturation of the Jurassic source rock during burial (Jensen and Schmidt, 1993; Danielsen et al., 1997). The pockmarks in the study area in the southern Danish Central Graben are located in a hydrocarbon producing area. The possible source rocks that were mature for hydrocarbon generation during the Danian were the Bryne Formation and possibly the Lulu and Lola Formations (Kubala et al., 2003; Petersen et al., 2008). These source rocks covered the southern part of the Danish Central Graben (Figs. 2 and 3) and could have provided light oil and/or condensate by vertical migration. Most of the pockmarks are located around salt structures (see Fig. 5), which form potential fluid flow barriers contributing to overpressure build up within the sediments (Kukla et al., 2011). The concentration of pockmarks around salt structures possibly indicates that their flanks may have focused the vertical migration of overpressure fluids (Lewis and Holness, 1996; Reuning et al., 2009; Andresen et al., 2011). In this line of arguments it should be noted that gas sampled in the water column immediately above the "Delta"-salt diapir of the Tommeliten field of the Norwegian sector of the North Sea (Hovland and Judd, 1988) was of themogenic origin. This example documents that there may exist fluid flow around and also above salt diapirs (Lewis and Holness, 1996; Schroot et al., 2005). It should also be noted that Hovland and Judd (1988) and Judd and Hovland (2007) describe pockmark features and active gas seeps above the buried "Delta"-salt diapir. It has also been suggested that gas seepage could be initiated by salt tectonic movement that can possibly create sub-seismic fractures contributing to fluid escape (Etiope et al., 2006). This mechanism might have facilitated vertical fluid migration in the study area since salt tectonic movements in the central North Sea were active during the entire Late Cretaceous and Palaeocene (Fig. 2).

Fehmers et al. (2012) have mapped gas charge for the Tyra Field with consequent discharge in the early Tertiary. Seismic data indicate the presence of vertical gas chimneys that extend from the Callovian level into the Top Chalk reservoir along a major fault. Fehmers et al. (2012) further documented the presence of limestone stringers in the Eocene-Oligocene units of the Tyra Field. Stable isotope analyses 
suggest that these limestones possibly formed by organisms supported by venting of methane of (partially?) thermogenic origin. Additionally, Sandrin et al. (2012) showed at Tyra that polygonal faults occur within the Tor Formation (Maastrichtian) below the Top Chalk reservoir (Danian). These structures may have acted as additional pathways for vertically migrating hydrocarbons (Hustoft et al., 2007; Antrett et al., 2012).

In general pockmarks tend to have a circular shape if they are formed by fluid escape from a point source (Hovland et al., 2002; Betzler et al., 2011). The sub-circular pockmarks of Type 1 (Fig. 7) therefore likely represent this initial stage of pockmark formation. Originally, the elongated pockmarks of Type 2 and 3 might also have been circular. Thus the length of the short axis of the elongated pockmarks gives us a general idea about their initial minimum size (Andresen et al., 2008). Elongated pockmarks can form by merging of circular pockmarks especially through gas escape from line sources, such as faults (Çifçi et al., 2003). However, the elongated pockmarks of Type 2 and 3 are characterized by smooth elliptical rims and an apparent lack of a direct structural control (Fig. 11). Bottom currents are thought to play an important role in the formation of pockmarks (Cathles et al., 2010). Elongated pockmarks are often interpreted to reflect bottom current erosion (Andresen et al., 2008; Dandapath et al., 2010). Consequently, we interpret that the elongation and mostly uniform orientation of the pockmarks of Type 2 and 3 is associated with bottom currents. The long axes of these depressions strike either SE-NW $\left(140^{\circ}-160^{\circ}\right.$, $74 \%)$ or E-W $\left(90^{\circ}-100^{\circ}, 26 \%\right.$; Fig. 9). The SE-NW orie ntation is generally subparallel to the reconstructed contour lines of the Mid-Palaeocene bathymetry after Gemmer et al. (2002), possibly indicating that the bottom currents belonged to a larger oceanic current system (Fig. 12). The E-W orientation, however, might reflect a bottom-flow direction deviating from the main trend possibly controlled by varying seafloor morphology.

In the study area, most of the elongated pockmarks are asymmetrical. According to Josenhans et al. (1978) the asymmetry can be explained by current impingement on the pockmark wall or a deflection of the fluid plume escaping the pockmark. In both cases erosion would be most intense on the downstream side of the pockmark, leading to an elongate shape with the deepest point situated on the upstream side of the pockmark (Fig. 13). Some erosion might also occur at the upstream wall of the pockmark if current velocity is sufficiently high to induce turbulence (Josenhans et al., 1978; Andresen et al., 2008). Such a scenario with simultaneous erosion on the upand downstream side of the pockmarks could explain why some of the elongated pockmarks (Type 2) are symmetrical. This view is supported by numerical-modelling results that show that eddies can form by converging currents on the upstream side of pockmarks (Hammer et al., 2009) due to an increase in the length of the water column inside the pockmark and an associated pressure drop (Fig. 13). The majority of the asymmetrical (Type 3) pockmarks in our study area are characterized by deepest points situated toward the SE or E, suggesting a contour current flow directed towards the NW and W during Danian times (Fig. 12). This direction is similar to the reconstruction of bottom-current flow towards the NW from the Maastrichtian succession of the Danish Basin, which was interpreted to belong to a larger circulation system linking the Tethys to the Boreal Sea (Lykke-Andersen and Surlyk, 2004; Surlyk and Lykke-Andersen, 2007; Esmerode et al., 2007). On the other hand, it is opposite to the interpretation of SE-ward oriented currents from the Maastrichtian of the Norwegian Central Graben (Gennaro et al., 2013) and the 
Maastrichtian to Danian succession from the German North-Sea (Surlyk et al., 2008). Hitherto, it is unclear if these different reconstructed bottom-current directions reflect temporal changes, variation of current direction with water depth or mesoscale eddy currents.

The elongated Type 2 and 3 depressions are concentrated at the SE flank of the Skjold diapir and in some distance away from the diapir. This distribution pattern could result from the interaction of the bottom currents with the seafloor topography created by salt diapirism during the Danian (Fig. 2). The influence of seafloor topography on the oceanic flow regime was studied intensively for seamounts (Beckmann and Mohn, 2002) and was compared to sedimentation patterns in the vicinity of salt domes (Lowrie, 1984). The circulation pattern created by seafloor topography can be very complex. When water is flowing over a domal structure at the sea floor, the water is forced to move upward and sideward possibly creating eddies. Generally, this can lead to a deceleration of the flow on the upcurrent and downcurrent side of the obstacle and acceleration on its flanks (Lowrie, 1984). This deceleration of the flow regime could explain why the shape of most pockmarks directly adjacent to the salt dome (Type 1) was not overprinted by the regional current system. The elongated pockmarks on the SE flank of the diapir (Type 2 and 3 ) in contrast could be caused by erosion by the deflected and accelerated waters. This is consistent with the observation of moats forming on the sides of seamounts due to the same affect (Lowrie and Heezen, 1967; Johnson and Lonsdale, 1976; Lowrie, 1984). Consequently, all depressions could have formed simultaneously as Type 1 pockmarks. The pockmarks that were sheltered by the sea-floor topography from scouring bottom currents remained unchanged. In contrast, pockmarks that were exposed to accelerated bottom currents were modified to Type 2 and 3 . This would be consistent with the observation that all pockmark types appear concurrently at ca. 25 ms below the Top Chalk surface.

All types of depressions show either $\mathrm{U}$ or $\mathrm{V}$-shapes in cross section (Figs. 7 and 8). Generally, U-shapes represent the more common, of all depression types. However, in Type $1 \mathrm{U}$ - and $\mathrm{V}$ - shapes are nearly equally common, while Type 2 and 3 depressions are clearly dominated by U-shapes (62 and $82 \%$ respectively). The Vshaped depressions most likely represent erosion from a point source due to fluid escape during the initial stage of pockmark development (Fig. 13). This initial shape presumably was later overprinted to a U-shape by processes that led to erosion of the pockmark walls, such as slumping or current scour (Betzler et al., 2011). This is consistent with the fact that V-shapes are more common in Type 1 depressions, which are interpreted to represent the initial pockmark morphology. The morphology of Type 2 and 3 depressions was interpreted to be overprinted by bottom currents. The predominance of U-shapes in these groups therefore might also be caused by erosive bottom currents (Kilhams et al., 2011). Alternatively, slumping of the pockmark wall was proposed to modify the morphology of pockmarks from a $\mathrm{V}$ - to a U-shape (Dimitrov and Dontcheva, 1994). Betzler et al. (2011) observed irregular and mounded layering at the bottom of large bowl shaped pockmarks in fine-grained carbonates of the Maldives Archipelago. They interpreted these deposits as slumps originating from the pockmark walls (Fig. 13). The rapid expulsion of fluids along the sidewall of the pockmarks might have contributed to sediment instability and slumping towards the centre (Dandapath et al., 2010). 


\section{Conclusions}

Three-dimensional (3D) seismic data were used to analyse the morphology and spatial distribution of circular/elliptical depression features in the Danian Chalk of the southern Danish North Sea. Three types of pockmarks were differentiated based on their plan view geometry and degree of symmetry: Type 1 depressions which are sub-circular and symmetrical. Elongated and symmetrical Type 2 depressions that represent only a small fraction. The depression Type 3 is elongated and asymmetrical. All depressions occur in an interval from ca. $25 \mathrm{~ms}$ below to $12 \mathrm{~ms}$ above the Top Chalk surface. The reduction in amplitude above the Top Chalk surface is interpreted as a later drape and passive infill of the topography created by the pockmarks. The interval down to $25 \mathrm{~ms}$ below the Top Chalk surface is situated completely within the Ekofisk Formation, thus dating the pockmarks formation to the Danian.

Expulsion of biogenic or thermogenic fluids is suggested as the main driver for the pockmark formation during the Danian. The main Jurassic source rocks which were mature during the Danian could have provided light oil and/or condensate by vertical migration. Most pockmarks are situated close to salt diapirs (Skjold and Dan), possibly indicating that their flanks may have acted as foci for the vertical migration of fluids. The sub-circular pockmarks of Type 1 likely represent the most original stage of pockmark formation, whereas the elongated pockmarks of Type 2 and 3 were most likely modified by bottom currents. The majority of the elongated pockmarks in our study area are asymmetrical with the deepest points situated toward the SE or E, indicating a current flow directed towards the NW and W. The distribution of the elongated pockmarks around the Skjold salt dome suggests that contour currents might have interacted with the sea-floor morphology created by the diapir. The scarcity of elongated pockmarks on the up- and down-current flanks of the diapir possibly indicates a deceleration of the bottom current velocity at these locations.

\section{Acknowledgements}

The authors thank Maersk Olie og Gas, Shell EPE Geological Services and the DUC Partners for initiating and supporting this study. Schlumberger and Seismic MicroTechnology are thanked for providing 'PETREL' and 'KINGDOM Software' under an Academic User License Agreement. Personally thanked are T. Fronval, A. Uldall, J. Grötsch, H. Krabbe and F. van Buchem for discussions and their project input. We gratefully acknowledge IJES-Editors W-Chr. Dullo and Chr. Hübscher as well as reviewers $M$. Hovland and $S$. Bünz for their comments and suggestions that significantly helped to improve an earlier version of the manuscript.

\section{References}

Andresen, K. J., Huuse, M., and Clausen, O. R., 2008, Morphology and distribution of Oligocene and Miocene pockmarks in the Danish North Sea - implications for bottom current activity and fluid migration: Basin Research, v. 20, no. 3, p. 445-466.

Andresen, K. J., Huuse, M., Schodt, N. H., Clausen, L. F., and Seidler, L., 2011, Hydrocarbon plumbing systems of salt minibasins offshore Angola revealed by three-dimensional seismic analysis: AAPG Bulletin, v. 95, no. 6, p. 1039-1065. 
Antrett, P., Vackiner, A. A., Kukla, P. A., Back, S., and Stollhofen, H., 2012, Controls on reservoir compartmentalization of an Upper Permian tight gas field in Germany and links to a modern analogue in the western US: Petroleum Geoscience, v. 18, no. 3, p. 289-304.

Back, S., Van Gent, H., Reuning, L., Grotsch, J., Niederau, J., and Kukla, P., 2011, 3D seismic geomorphology and sedimentology of the Chalk Group, southern Danish North Sea: Journal of the Geological Society, v. 168, no. 2, p. 393-405.

Barmwell, N. P., Gaillet, G., Meciani, N., Judge, N. C., Green, M., and Adam, P., 1999, Chalk exploration, the search for the subtle trap, in Fleet, A. J., and Boldy, A. A. R., eds., Petroleum geology of North West Europe. Proceeding of the fifth Conference, Geological Society London p. 911-938.

Beckmann, A., and Mohn, C., 2002, The upper ocean circulation at Great Meteor Seamount: Ocean Dynamics, v. 52, no. 4, p. 194-204.

Betzler, C., Lindhorst, S., Hübscher, C., Lüdmann, T., Fürstenau, J., and Reijmer, J., 2011, Giant pockmarks in a carbonate platform (Maldives, Indian Ocean): Marine Geology, v. 289, no. 1-4, p. 1-16.

Bizarro, P., 1998, Subcircular features and autotracking artefacts in 3D seismic interpretation: a case study from the central North sea: Petroleum Geoscience, v. 4 , no. 2 , p. $173-179$.

Brewster, J., and Dangerfield, J. A., 1984, Chalk fields along the Lindesnes Ridge, Eldfisk: Marine and Petroleum Geology, v. 1, no. 3, p. 239-278.

Bromley, R. G., and Ekdale, A. A., 1987, Mass-Transport in European Cretaceous Chalk - Fabric Criteria for Its Recognition: Sedimentology, v. 34, no. 6, p. 1079-1092.

Brown, A., 1999, Interpretation of Three-Dimensional Seismic Data, AAPG and SEG: Tulsa, Oklahoma, USA, AAPG Memoir 42 and SEG Investigations in Geophysics 9.

Bünz, S., Mienert, J., and Berndt, C., 2003, Geological controls on the Storegga gashydrate system of the mid-Norwegian continental margin: Earth and Planetary Science Letters, v. 209, no. 3-4, p. 291-307.

Bøe, R., Rise, L., and Ottesen, D., 1998, Elongate depressions on the southern slope of the Norwegian Trench (Skagerrak): morphology and evolution: Marine Geology, v. 146, no. 1-4, p. 191-203.

Cartwright, J. A., 1989, The kinematics of inversion in the Danish Central Graben: Geological Society, London, Special Publications, v. 44, no. 1, p. 153-175.

Cathles, L. M., Su, Z., and Chen, D., 2010, The physics of gas chimney and pockmark formation, with implications for assessment of seafloor hazards and gas sequestration: Marine and Petroleum Geology, v. 27, no. 1, p. 891.

Çifçi, G., Dondurur, D., and Ergun, M., 2003, Deep and shallow structures of large pockmarks in the Turkish shelf, Eastern Black Sea: Geo-Marine Letters, v. 23, no. 3-4, p. 311-322.

Clausen, O. R., and Huuse, M., 1999, Topography of the Top Chalk surface on- and offshore Denmark: Marine and Petroleum Geology, v. 16, no. 7, p. 677-691.

Cole, D., Stewart, S. A., and Cartwright, J. A., 2000, Giant irregular pockmark craters in the Palaeogene of the Outer Moray Firth Basin, UK North Sea: Marine and Petroleum Geology, v. 17, no. 5, p. 563-577.

Dandapath, S., Chakraborty, B., Karisiddaiah, S. M., Menezes, A., Ranade, G., Fernandes, W., Naik, D. K., and Raju, K. N. P., 2010, Morphology of pockmarks along the western continental margin of India: Employing multibeam bathymetry and backscatter data: Marine and Petroleum Geology, v. 27 , no. 10 , p. $2107-2117$. 
Danielsen, M., Michelsen, O., and Clausen, O. R., 1997, Oligocene sequence stratigraphy and basin development in the Danish North Sea sector based on log interpretations: Marine and Petroleum Geology, v. 14, no. 7-8, p. 931-950.

Deegan, C. E., and Scull, B. J., 1977, A proposed standard lithostratigraphic nomenclature for the central and northern North Sea, Report of the institute of Geological Sciences.

Dimitrov, L., and Dontcheva, V., 1994, Seabed pockmarks in the Southern Bulgarian Black Sea zone: Bulletin of the Geological Society of Denmark, v. 41, p. 24-33.

Esmerode, E. V., Andersen, H. L., and Surlyk, F., 2008, Interaction between bottom currents and slope failure in the late cretaceous of the southern Danish Central Graben, North Sea: Journal of the Geological Society, v. 165, p. 5572.

Esmerode, E. V., Lykke-Andersen, H., and Surlyk, F., 2007, Ridge and valley systems in the Upper Cretaceous chalk of the Danish Basin: contourites in an epeiric sea: Geological Society, London, Special Publications, v. 276, p. 265282.

Etiope, G., Papatheodorou, G., Christodoulou, D. P., Ferentinos, G., Sokos, E., and Favali, P., 2006, Methane and hydrogen sulfide seepage in the northwest Peloponnesus petroliferous basin (Greece): Origin and geohazard: AAPG Bulletin, v. 90, no. 5, p. 701-713.

Evans, D. J., Hopson, P. M., Kirby, G. A., and Bristow, C. R., 2003, The development and seismic expression of synsedimentary features within the Chalk of southern England: Journal of the Geological Society, v. 160, p. 797-813.

Fader, G. B. J., 1991, Gas-related sedimentary features from the eastern Canadian continental shelf: Continental Shelf Research, v. 11, p. 1123-1153.

Farmer, C. L., and Barkved, O. I., 1999, Influence of syn-depositional faulting on thickness variations in chalk reservoirs -Valhall and Hod fields: Geological Society, London, Petroleum Geology Conference Series, v. 5, p. 949-957.

Fehmers, G. C., Printz, B., and Febriany, G., 2012, Mapping of Gas Migration into, and out of, the Tyra Field in the Danish North Sea.: 74th EAGE Conference \& Exhibition incorporating SPE EUROPEC 2012 , Paper Z020 74th.

Gay, A., Lopez, M., Cochonat, P., Seranne, M., Levache, D., and Sermondadaz, G., 2006, Isolated seafloor pockmarks linked to BSRs, fluid chimneys, polygonal faults and stacked Oligocene-Miocene turbiditic palaeochannels in the Lower Congo Basin: Marine Geology, v. 226, no. 1-2, p. 25-40.

Gemmer, L., Huuse, M., Clausen, O. R., and Nielsen, S. B., 2002, Mid-Palaeocene palaeogeography of the eastern North Sea basin: integrating geological evidence and 3D geodynamic modelling: Basin Research, v. 14, no. 3, p. 329346.

Gennaro, M., Wonham, J. P., Gawthorpe, R., and Sælen, G., 2013, Seismic stratigraphy of the Chalk Group in the Norwegian Central Graben, North Sea: Marine and Petroleum Geology v. 45, p. 236-266.

Hancock, J. M., 1975, The Petrology of the Chalk: Proceedings of the Geologists' Association, v. 86, no. 4, p. 499-535.

Haq, B. U., Hardenbol, J. A. N., and Vail, P. R., 1988, Mesozoic and Cenozoic chronostratigraphy and cycles of sea-level change Sea-Level Changes, Volume 42, SEPM (Society for Sedimentary Geology), p. 71-108.

Hardman, R. F. P., 1982, Chalk reservoirs of the North Sea: Bulletin of the Geological Society of Denmark, v. 30, p. 119-137.

Hatton, I. R., 1986, Geometry of Allochthonous Chalk Group Members, Central Trough, North-Sea: Marine and Petroleum Geology, v. 3, no. 2, p. 79-98. 
Heggland, R., 1998, Gas seepage as an indicator of deeper prospective reservoirs. A study based on exploration 3D seismic data: Marine and Petroleum Geology, v. 15 , no. 1 , p. 1-9.

Hemmet, M., 2005, The hydrocarbon potential of the Danish Continental Shelf: Geological Society, London, Petroleum Geology Conference Series, v. 6, p. 85-97.

Hovland, M., 1982, Pockmarks and the Recent Geology of the Central Section of the Norwegian Trench: Marine Geology, v. 47, no. 3-4, p. 283-301.

Hovland, M., 1983, Elongated Depressions Associated with Pockmarks in the Western Slope of the Norwegian Trench: Marine Geology, v. 51, no. 1-2, p. 35-46.

Hovland, M., 1984, Gas-Induced Erosion Features in the North-Sea: Earth Surface Processes and Landforms, v. 9, no. 3, p. 209-228.

Hovland, M., Gardner, J. V., and Judd, A. G., 2002, The significance of pockmarks to understanding fluid flow processes and geohazards: Geofluids, v. 2, no. 2, p. 127-136.

Hovland, M., Heggland, R., De Vries, M. H., and Tjelta, T. I., 2010, Unit-pockmarks and their potential significance for predicting fluid flow: Marine and Petroleum Geology, v. 27, no. 6, p. 1190-1199.

Hovland, M., and Judd, A. G., 1988, Seabed pockmarks and seepages. Impact on geology, biology and the marine environment: London, Graham \& Trotman, $p$. 293.

Hovland, M., Svensen, H., Forsberg, C. F., Johansen, H., Fichler, C., Fosså, J. H., Jonsson, R., and Rueslåtten, H., 2005, Complex pockmarks with carbonateridges off mid-Norway: Products of sediment degassing: Marine Geology, v. 218, no. 1- 4, p. 191-206.

Hustoft, S., Mienert, J., Bunz, S., and Nouze, H., 2007, High-resolution 3D-seismic data indicate focussed fluid migration pathways above polygonal fault systems of the mid-Norwegian margin: Marine Geology, v. 245, no. 1-4, p. 89-106.

Huuse, M., 1999, Detailed morphology of the Top Chalk surface in the eastern Danish North Sea: Petroleum Geoscience, v. 5, no. 3, p. 303-314.

Huuse, M., Lykke-Andersen, H., and Michelsen, O., 2001, Cenozoic evolution of the eastern Danish North Sea: Marine Geology, v. 177, no. 3-4, p. 243-269.

Immenhauser, A., Dublyansky, Y. V., Verwer, K., Fleitmann, D., and Pashenko, S. E., 2007, Textural, elemental, and isotopic characteristics of Pleistocene phreatic cave deposits (Jabal Madar, Oman): Journal of Sedimentary Research, v. 77, no. $1-2$, p. 68-88.

Isaksen, D., and Tonstand, K., 1989, A revised Cretaceous and Tertiary lithostratigraphic nomenclature for the Norwegian North Sea: Bulletin of Norwegian Petroleum Directorate, v. 5, p. 65.

Japsen, P., 1998, Regional velocity-depth anomalies, North Sea Chalk: A record of overpressure and neogene uplift and erosion: AAPG Bulletin, v. 82, no. 11, p. 2031-2074.

Jensen, L. N., and Schmidt, B. J., 1993, Neogene uplift and erosion offshore South Norway: magnitude and consequences for hydrocarbon exploration in the Farsund Basin: Generation, Accumulation and Production of Europels Hydrocarbons III, 3. Special Publications, v. 3, p. 79-88.

Johnson, D. A., and Lonsdale, P. F., 1976, Erosion and sedimentation around Mytilus Seamount, New England continental rise: Deep Sea Research and Oceanographic Abstracts, v. 23, no. 5, p. 429-440. 
Johnson, H., Leslie, A. B., Wilson, C. K., Andrews, I. J., and Cooper, R. M., 2005, Middle Jurassic, Upper Jurassic and Lower Cretaceous of the UK Central and Northern North Sea: British Geological Survey Research Report, RR/03/001.

Johnson, H., and Lott, G. K., 1993, Cretaceous of the Central and Northern North Sea, in Knox, R. W. O. B., and Cordey, W. G., eds., Lithostratigraphic Nomenclature of the UK North Sea, Volume 2, Nottingham: British Geological Survey.

Josenhans, H. W., King, L. H., and Fader, G. B., 1978, A side-scan sonar mosaic of pockmarks on the Scotian Shelf: Canadian Journal of Earth Sciences, v. 15, no. 5, p. 831-840.

Judd, A., and Hovland, M., 2007, Seabed fluid flow-the impact on geology, Biology and the Marine Environment, Cambridge University Press, New York, p. 475.

Kelley, J. T., Dickson, S. M., Belknap, D. F., Barnhardt, W. A., and Henderson, M., 1994, Giant Sea-Bed Pockmarks - Evidence for Gas Escape from Belfast Bay: Maine Geology, v. 22, no. 1, p. 59-62.

Kennedy, W. J., 1980, Aspects of chalk sedimentation the southern Norwegian offshore: The Sedimentation of the North Sea Reservoir Rocks, Norsk Petroleums Forening, Geilo, p. 1-29.

Kennedy, W. J., 1987, Sedimentology of Late Cretaceous- Palaeocene chalk reservoirs, North Sea Central Graben, in Brooks, J., and Glennie, K. W., eds., Petroleum geology of north-west Europe, Graham \& Trotman, London, p. 469481.

Kilhams, B., McArthur, A., Huuse, M., Ita, E., and Hartley, A., 2011,Enigmatic largescale furrows of Miocene to Pliocene age from the central North Sea: currentscoured pockmarks?. Geo-Marine Letters, v. 31, no. 5-6, p. 437-449.

King, L. H., and MacLean, B., 1970, Pockmarks on the Scotian Shelf: Geological Society of America Bulletin, v. 81, no. 10, p. 3141-3148.

Kubala, M., Bastow, M., Thompson, S., Scotchman, I., and Oygard, K., 2003, Geothermal Regime, Petroleum Generation and Migration, in Evans, D., Graham, C., Armour, A., and Bathurst, P., eds., The Millennium Atlas: Petroleum Geology of the Central and Northern North Sea, The Geological Society of London, London, p. 289-315.

Kukla, P. A., Reuning, L., Becker, S., Urai, J. L., and Schoenherr, J., 2011, Distribution and mechanisms of overpressure generation and deflation in the late Neoproterozoic to early Cambrian South Oman Salt Basin: Geofluids, v. 11 , no. 4, p. 349-361.

León, R., Somoza, L., Medialdea, T., Hernández-Molina, F., Vázquez, J., Díaz-delRio, V., and González, F., 2010, Pockmarks, collapses and blind valleys in the Gulf of Cádiz: Geo-Marine Letters, v. 30, no. 3-4, p. 231-247.

Lewis, S., and Holness, M., 1996, Equilibrium halite-H2O dihedral angles: High rocksalt permeability in the shallow crust?: Geology, v. 24, no. 5, p. 431-434.

Lieberkind, K., Bang, I., Mikkelsen, N., and Nygaard, E., 1982, Late Cretaceous and Danian limestone, in Michelsen, O., ed., Geological survey of Denmark., p. 4962.

Lowrie, A., 1984, Sediment distribution around salt domes and ridges on the Louisiana slope: Gulf Coast Association of Geological Societies Transactions, v. 34, p. 123-130.

Lowrie, A., and Heezen, B. C., 1967, Knoll and Sediment Drift near Hudson Canyon: Science, v. 157, no. 3796, p. 1551553. 
Lykke-Andersen, H., and Surlyk, F., 2004, The Cretaceous-Palaeogene boundary at Stevns Klint, Denmark: inversion tectonics or sea-floor topography?. Journal of the Geological Society, v. 161, p. 343-352.

Michelsen, O., Nielsen, L. H., Johannessen, P. N., Andsbjerg, J., and Surlyk, F., 2003, The Jurassic of Denmark and Greenland: Jurassic lithostratigraphy and stratigraphic development onshore and offshore Denmark: Geological Survey of Denmark and Greenland Bulletin v. 1, p. 145-216.

Morton, A. C., Hallsworth, C. R., and Wilkinso, G. C., 1993, Stratigraphic evolution of sand provenace during Paleocene deposition in the Northern North Sea area, in Parker, J. R., ed., Petroleum Geology of Northwest Europe: Proceeding of the 4th Conference, London: The Geological Society of London p. 73-84.

Motimer, C. P., 1987, Upper Cretaceous Calcareous Nannofossil Biostratigraphy of the Southern Norwegian and Danish North Sea Area.Abhandhmgen Geol. B.A., v. 39, p. 143-175.

Munns, J. W., 1985, The Valhall Field: a geological overview: Marine and Petroleum Geology, v. 2, no. 1, p. 23-43.

Palmer, A. N., 1991, Origin and Morphology of Limestone Caves: Geological Society of America Bulletin, v. 103, no. 1, p. 1-21.

Petersen, H. I., Nielsen, L. H., Bojesen-Koefoed, J. A., Mathiesen, A., Kristensen, L., and Dalhoff, F., 2008, Evaluation of the quality, thermal maturity and distribution of potential source rocks in the Danish part of the NorwegianDanish Basin: Geological Survey of Denmark and Greenland Bulletin, v. 16, p. 1-27.

Prior, D. B., Doyle, E. H., and Kaluza, M. J., 1989, Evidence for sediment eruption on deep-sea floor, Gulf of Mexico: Science, v. 243, no. 4890, p. 517-519.

Reuning, L., Schoenherr, J., Heimann, A., Urai, J. L., Littke, R., Kukla, P. A., and Rawahi, Z., 2009, Constraints on the diagenesis, stratigraphy and internal dynamics of the surface-piercing salt domes in the Ghaba Salt Basin (Oman): A comparison to the Ara Group in the South Oman Salt Basin: Geoarabia, v. 14, no. 3, p. 83-120.

Rosleff-Soerensen, B., Reuning, L., Back, S., and Kukla, P., 2012, Seismic geomorphology and growth architecture of a Miocene barrier reef, Browse Basin, NW-Australia: Marine and Petroleum Geology, v. 29, no. 1, p. 233-254.

Sandrin, A., Fehmers, G., Printz, B., Buchem, F. V., Uldall, A., and Hoffmann, U., Polygonal Faulting in Chalk - An Example at the Tyra Field, Danish North Sea, in Proceedings 74th EAGE Conference \& Exhibition incorporating SPE EUROPEC 2012 , Paper 1142012.

Schroot, B. M., Klaver, G. T., and Schuttenhelm, R. T. E., 2005, Surface and subsurface expressions of gas seepage to the seabed - examples from the Southern North Sea: Marine and Petroleum Geology, v. 22, no. 4, p. 499-515.

Stewart, S. A., 1999, Seismic interpretation of circular geological structures: Petroleum Geoscience, v. 5, no. 3, p. 273-285.

Sumida, P. Y. G., Yoshinaga, M. Y., Madureira, L., and Hovland, M., 2004, Seabed pockmarks associated with deepwater corals off SE Brazilian continental slope, Santos Basin: Marine Geology, v. 207, no. 1-4, p. 159-167.

Surlyk, F., 1997, A cool-water carbonate ramp with bryozoan mounds: Late Cretaceous-Danian of the Danish Basin: Carbonates. SEPM. Special Publications, v. 56, p. 293-307.

Surlyk, F., Dons, T., Clausen, C. K., and Higham, J., 2003, Upper Cretaceous, in Evans, D., Graham, C., Armour, A., and Bathurst, P., eds., The Millennium 
Atlas: Petroleum Geology of the Central and Northern North Sea. Geological Society, London, p. 213-233.

Surlyk, F., Jensen, S. K., and Engkilde, M., 2008, Deep channels in the CenomanianDanian Chalk Group of the German North Sea sector: Evidence of strong constructional and erosional bottom currents and effect on reservoir quality distribution: AAPG Bulletin, v. 92, no. 11, p. 1565-1586.

Surlyk, F., and Lykke-Andersen, H., 2007, Contourite drifts, moats and channels in the Upper Cretaceous chalk of the Danish Basin: Sedimentology, v. 54, no. 2, p. 405-422.

Swart, P. K., Wortmann, U. G., Mitterer, R. M., Malone, M. J., Smart, P. L., Feary, D. A., and Hine, A. C., 2000, Hydrogen sulfide-rich hydrates and saline fluids in the continental margin of South Australia: Geology, v. 28, p. 1039-1042.

Tóth, J., 1999, Groundwater as a geologic agent: An overview of the causes, processes, and manifestations: Hydrogeology Journal, v. 7, no. 1, p. 1-14.

Ussler, W., Paull, C. K., Boucher, J., Friederich, G. E., and Thomas, D. J., 2003, Submarine pockmarks: a case study from Belfast Bay, Maine: Marine Geology, v. 202, no. 3-4, p. 175-192.

van der Molen, A. S., van Heel, H. W. D., and Wong, T. E., 2005, The influence of tectonic regime on chalk deposition: examples of the sedimentary development and 3D-seismic stratigraphy of the Chalk Group in the Netherlands offshore area: Basin Research, v. 17, no. 1, p. 63-81.

Van Hoorn, B., 1987, Structure evolution, timing and tectonic style of the Sole Pit Inversion, in Ziegler, P. A., ed., Compressional intra-plate deformations in the Alpine Foreland, Volume 137, Tectonophysics, p. 239-284.

van Weering, T. C. E., Klaver, G. T., and Prins, R. A., 1997, Gas in marine sediments: Marine Geology, v. 137, no. 1-2, p. 1-3.

Van Wijhe, D. H., 1987, Structural evolution of inverted basins in the Dutch offshore: Tectonophysics, v. 137, no. 1-4, p. 171-219.

Vejbæk, O. V., and Andersen, C., 1987, Cretaceous-Early Tertiary inversion tectonism in the Danish Central Trough: Tectonophysics, v. 137, no. 1-4, p. 221-238.

Vejbæk, O. V., Bidstrup, T., Britze, P., Erlström, M., Rasmussen, E. S., and Sivhed, U., 2007, Chalk depth structure maps, Central to Eastern North Sea,Denmark: Geological Survey of Denmark and Greenland Bulletin, v. 13, p. 9-12.

Watts, N. L., Lapre, J. F., Vanschijndelgoester, F. S., and Ford, A., 1980, Upper Cretaceous and Lower Tertiary Chalks of the Albuskjell Area, North-Sea Deposition in a Slope and a Base-of-Slope Environment: Geology, v. 8, no. 5, p. 217-221.

Zanella, E., and Coward, M. P., 2003, Structural faramework, in Evans, D., Graham, C., Armour, A., and Bathurst, P., eds., The Millenium Atlas: Petroleum Geology of the Central and Northern North Sea, London: The Geological Society of London, p. 45-59.

Figure 1 a) Location of the study area in the Danish North Sea Central Graben. b) Structureattribute map (horizon slice) of the Top Chalk surface generated from 3D seismic-reflection data. The black horizontal line indicates the position of the seismic-reflectivity line shown below. c) Vertical reflectivity section illustrating the base and top of the Chalk Group. 
Figure 2 Chronostratigraphic and lithological context of the Upper Cretaceous succession (after Deegan and Scull, 1977; Lieberkind et al., 1982; Isaksen and Tonstad, 1989; Johnson and Lott, 1993). Chalk deposition was greatly influenced by halokinesis in addition to local fault-controlled subsidence or inversion (Zanella and Coward, 2003) and sea level (Haq et al., 1988). Also shown is the source rock maturity of the Bryne Formation (after Kubala et al., 2003).

Figure 3 a) Middle and Upper Jurassic lithostratigraphy from the Danish sector of the Central Graben, North Sea (after Michelsen et al., 2003). b) Location of depressions with respect to potential source rocks (after Kubala et al., 2003).

Figure 4 Seismic-to-well tie for the Top Chalk surface. The Top Chalk surface is characterized by an upward increase in gamma-ray, density and interval transit-time. On reflectivity data, this change commonly coincides with a seismic trough (well 1). In gasaffected areas, the continuity and amplitude of the reflection peak can be reduced or a polarity reversal can occur (well 2 ).

Figure 5 Structure-attribute maps of the Top Chalk surface within the study area. Depressions cluster in three areas: southwest of the Tyra-Igor Ridge (Area 1), the northwestern, southwestern and southeastern flanks of the Skjold salt-diapir (Area 2) and the southwestern flank of the Dan salt structure (Area 3). Black arrows exemplarily point to individual depressions.

Figure 6 Seismic cross section showing that the depressions are reduced in depth above the Top Chalk surface. This is interpreted as a passive drape of the pockmark morphology by post-Danian siliciclastic sediments.

Figure 7 Structure attribute maps and seismic sections along and across typical depressions: a) Sub-circular and symmetrical depressions (Type 1); b) Elongate and symmetrical depressions (Type 2); c) Elongate and asymmetrical depressions (Type 3). All depression types can either appear as U- or V-shaped in cross-section.

Figure 8 Schematic plan view geometry and cross-section shape of the three end-member types of depression and their relative abundance in the study area.

Figure 9 a) Plot of long vs. short axes length for all depressions from the Skold and Dan area. Ellipticity indices from 1.1 to 2.5 are shown as straight lines. b) Long axes orientation of the elongate depressions. The majority (74\%) of the long axes strike $140^{\circ}-160^{\circ}$ (NW-SE) and the minority $(26 \%)$ strike $90-100^{\circ}$ or $(\mathrm{W}-\mathrm{E})$.

Figure 10 a) Structure attribute map of the Top Chalk surface in the Skjold salt-dome area. b) Distribution of the three different depression types. The sub-circular depressions of Type 1 are dominantly located near the salt-diapir. Most of the elongate ones of Type 2 and 3 occur on the SW flank or further away from the salt dome. c) Distribution of different cross-sectional shapes. U- and V-shapes are nearly equally common in Type 1 depressions, but U-shapes clearly dominate depression Type 2 and 3 .

Figure 11 Structure attribute maps 25 ms (TWT) below Top Chalk, and vertical seismic reflectivity sections. Dashed lines indicate location of seismic sections. Solid lines represent faults. a) Pockmarks in the Tyra area showing a pockmark example possibly related to the migration of thermogenic gas from Middle Jurassic source rocks along faults. b) Pockmarks concentrating around the Skjold salt-diapir. This possibly indicates that the diapir flanks may have focused the vertical migration of overpressured fluids. c) Pockmarks of the Dan area; these pockmarks occur in the vicinity a fault formed above the Dan salt-dome, but trend in a 
different direction. Gas seepage could have been initiated by salt tectonic movement creating sub-seismic fractures contributing to fluid escape.

All pockmarks appear simultaneously at ca. $25 \mathrm{~ms}$ below the Top chalk surface with no apparent difference in timing between the three pockmark types. They can be traced as morphologic depressions up to $12 \mathrm{~ms}$ above the Top Chalk surface (Fig. 6). However, above the Top Chalk surface, the amplitude of the depressions diminishes continuously until they are unrecognizable in cross-section and map view. It is therefore assumed that the active pockmark formation ceased around the Top Chalk surface. The reduction in amplitude above the Top Chalk surface is interpreted as a later drape and passive infill of the topography created by the pockmarks (Fig. 6). The interval down to 25 ms below the Top Chalk surface is situated completely within the Ekofisk Formation, thus dating the pockmark formation to the Danian.

Figure 12 Palaeotopographic map of the Top Chalk surface (after Gemmer et al., 2002) with inferred bottom current directions derived from the orientation of the long axes of elongated pockmarks and the asymmetry of Type 3 depressions. Bottom currents of similar orientation were reconstructed for the Maastrichtian of the Danish Basin (DB, Lykke-Andersen and Surlyk, 2004; Surlyk and Lykke-Andersen, 2007).

Figure 13 Conceptual model for the development of different types of pockmark morphologies modified after Josenhans et al. (1978). Sub-circular, symmetrical Type 1 depressions are thought to show the original pockmark form during active venting. Elongated Type 2 and 3 depressions are interpreted to be overprinted by bottom currents eroding either both, up- and down-stream sides of the pockmark (symmetrical Type 2) or only the downstream side of the pockmark (asymmetrical Type 3). The extent of erosion on the upcurrent side depends on the current velocity and turbulence created by eddy currents. All three pockmark types can show V- or U-shapes. V-shaped depressions most likely represent the initial stage of pockmark development, later overprinted to a U-shape by processes eroding the pockmark walls, such as slumping or current scour. 

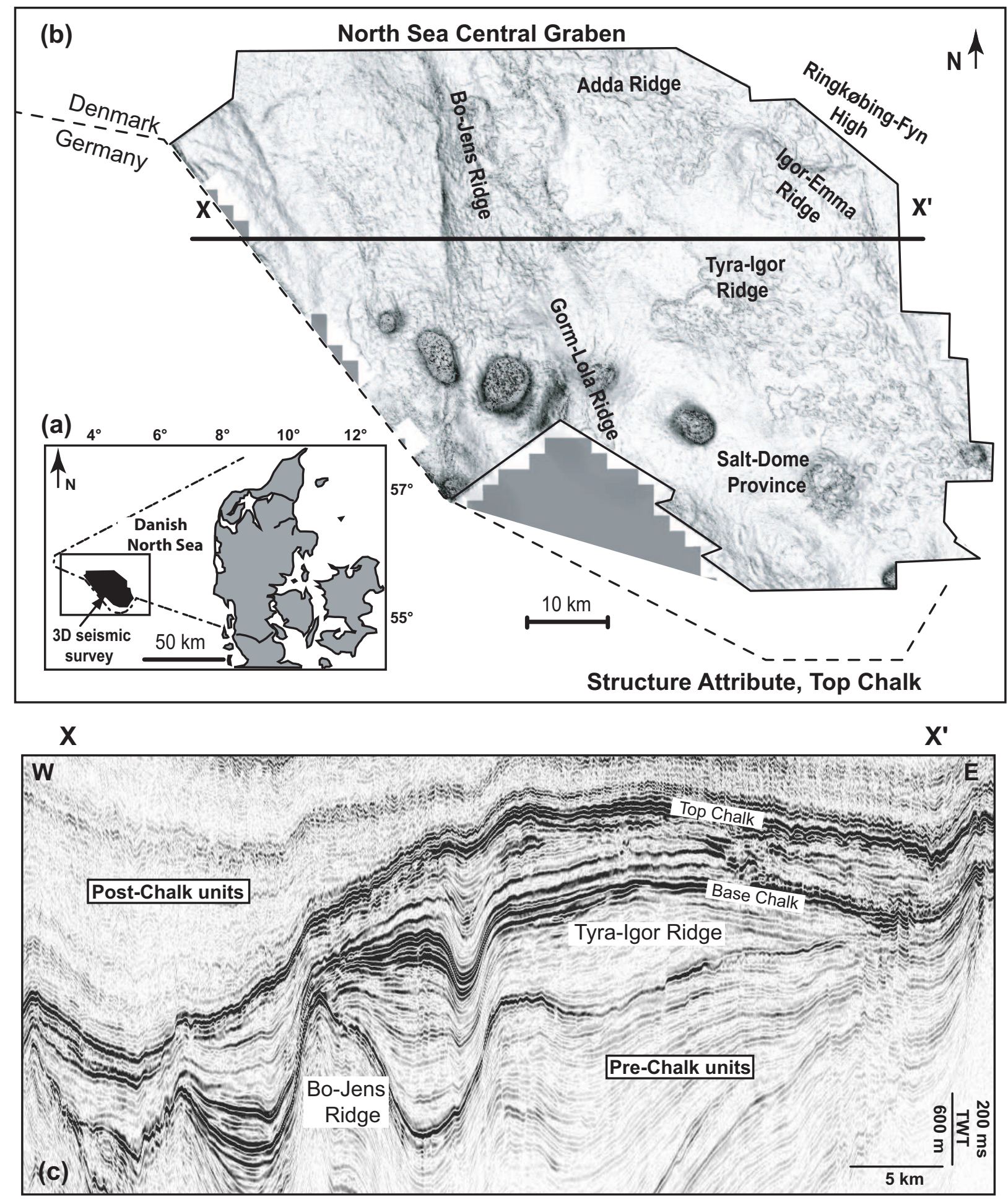

Fig. 1 


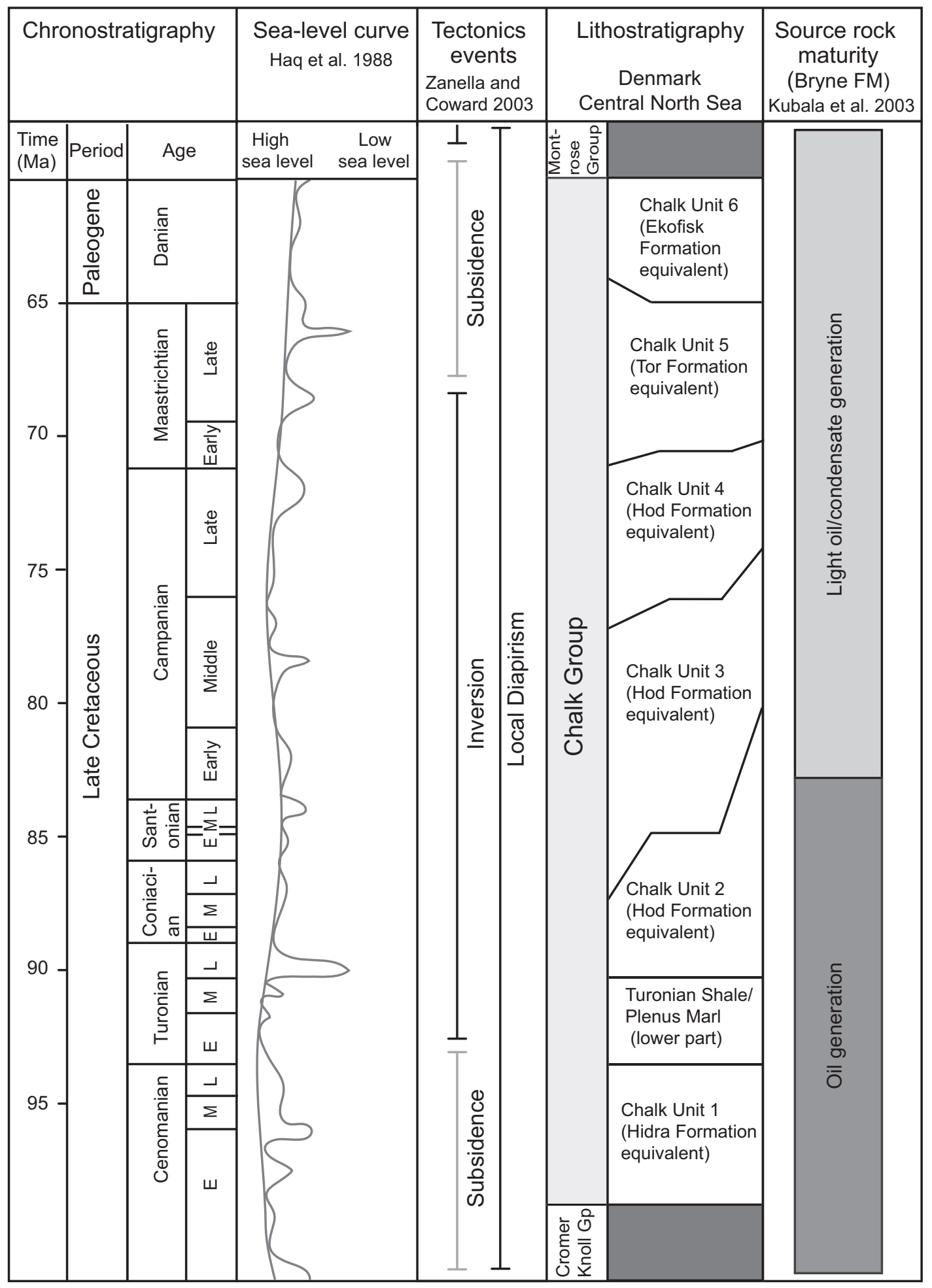

Fig. 2 


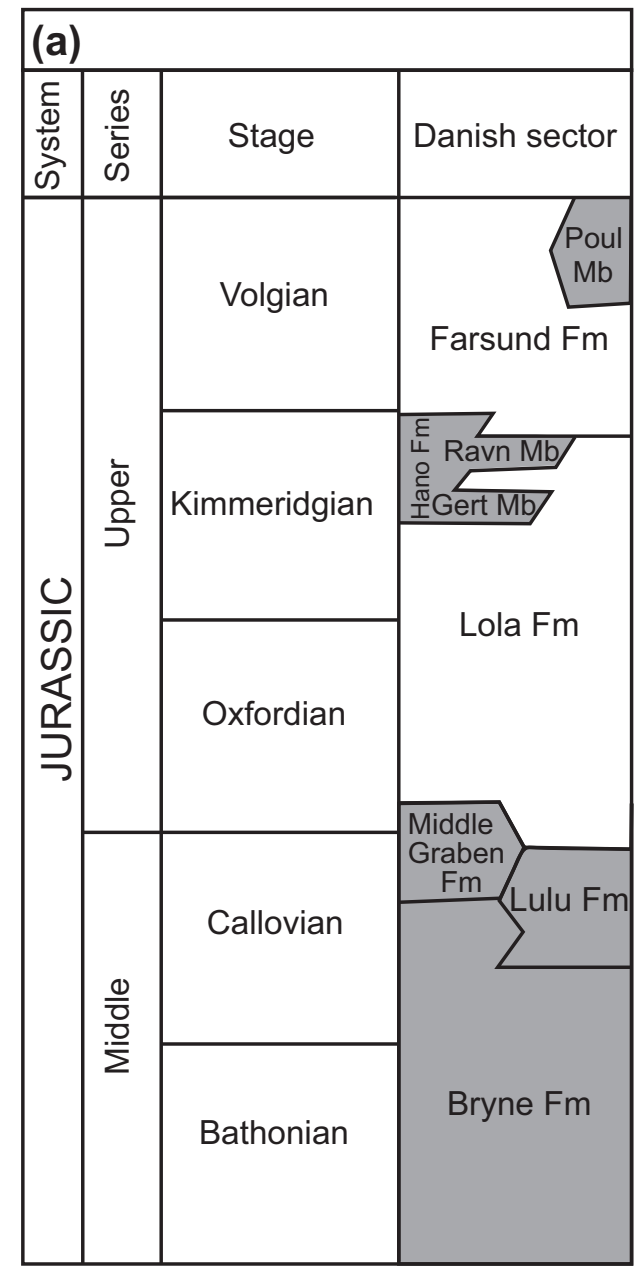

Sand-rich sediments

Clay-rich sediments

Fig. 3

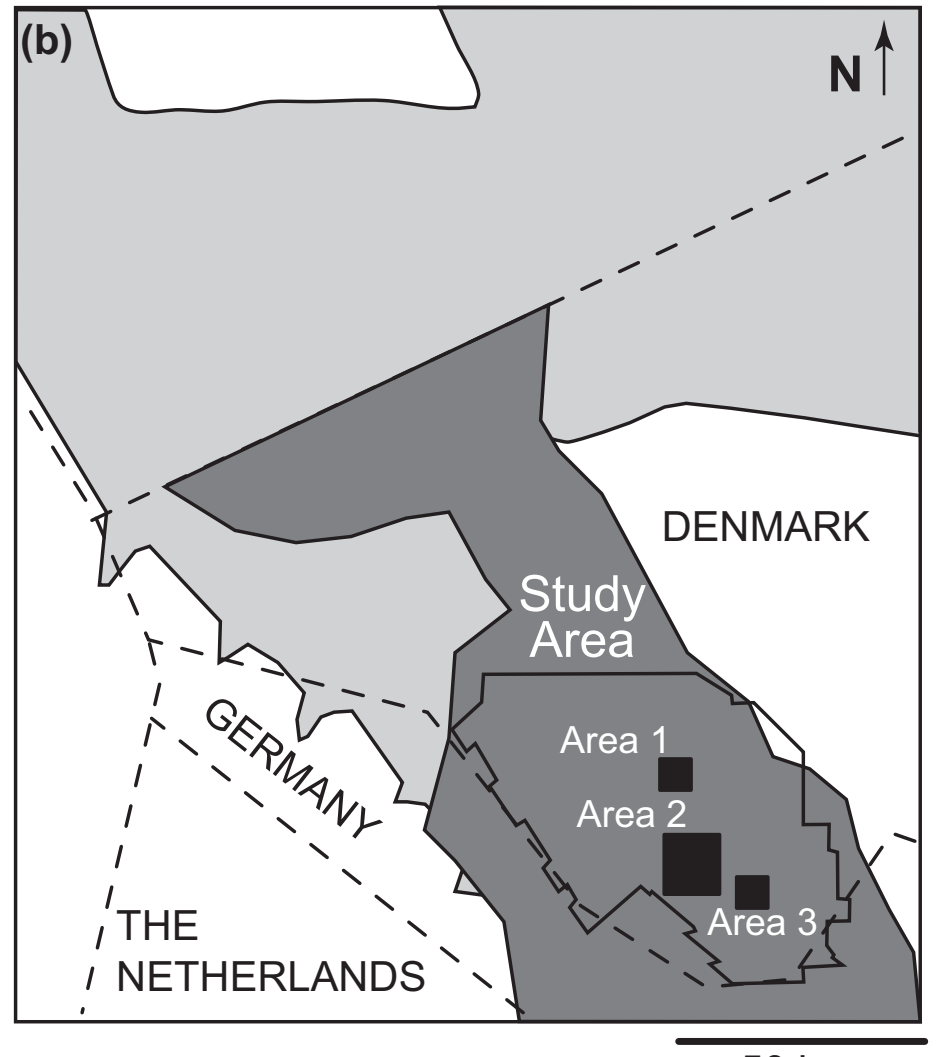

$50 \mathrm{~km}$

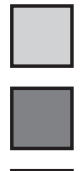

Lola Formation

Bryne and Lulu Formation

Location of depressions 


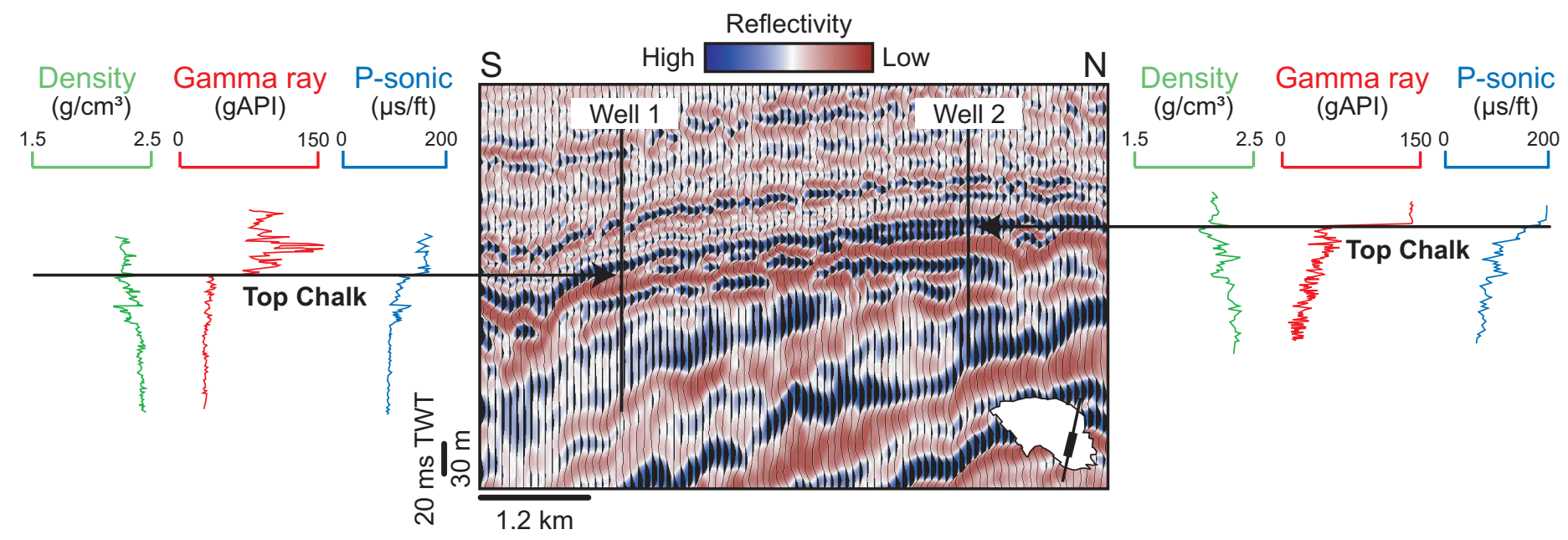

Fig. 4 

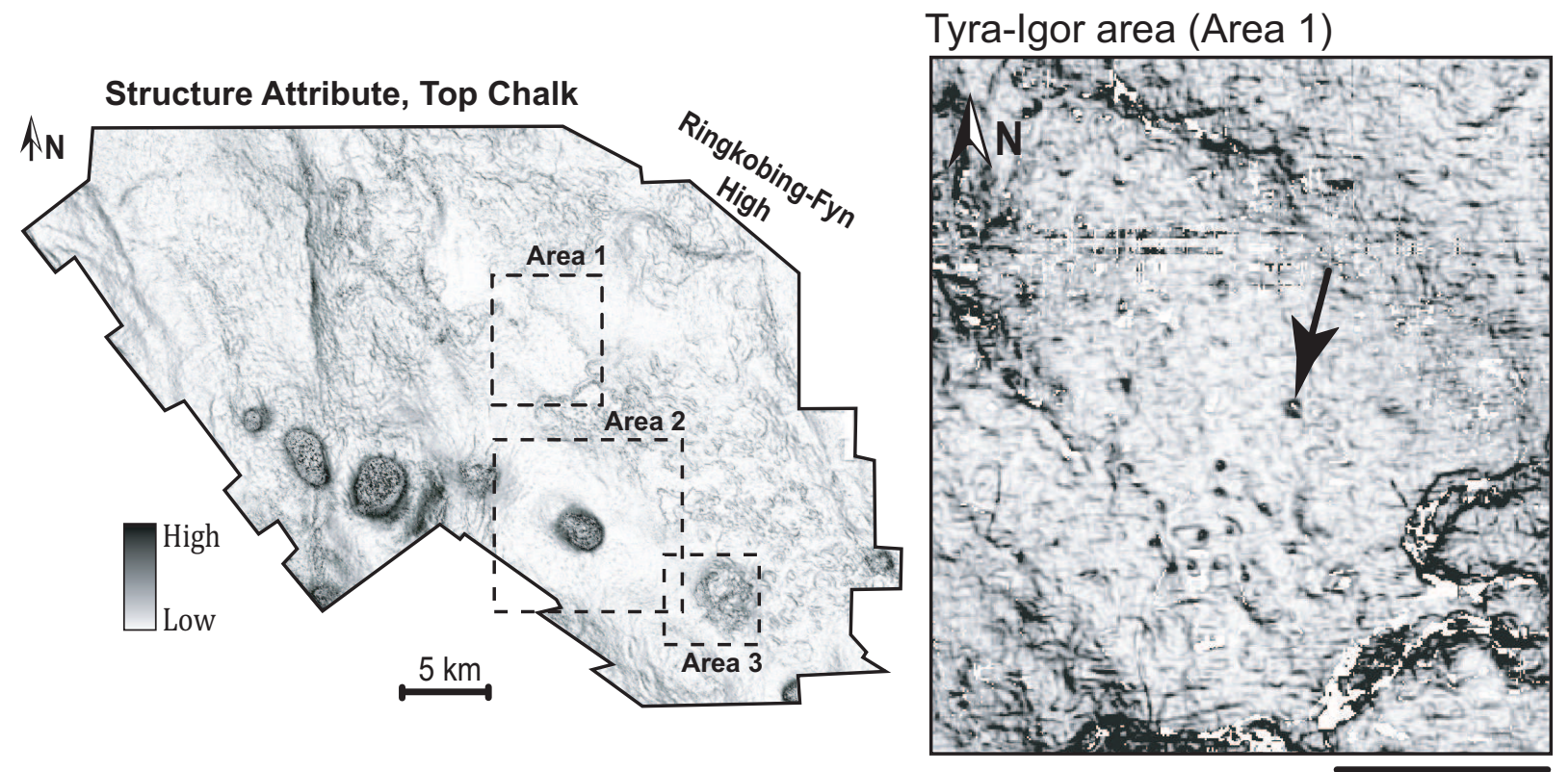

Skjold area (Area 2)

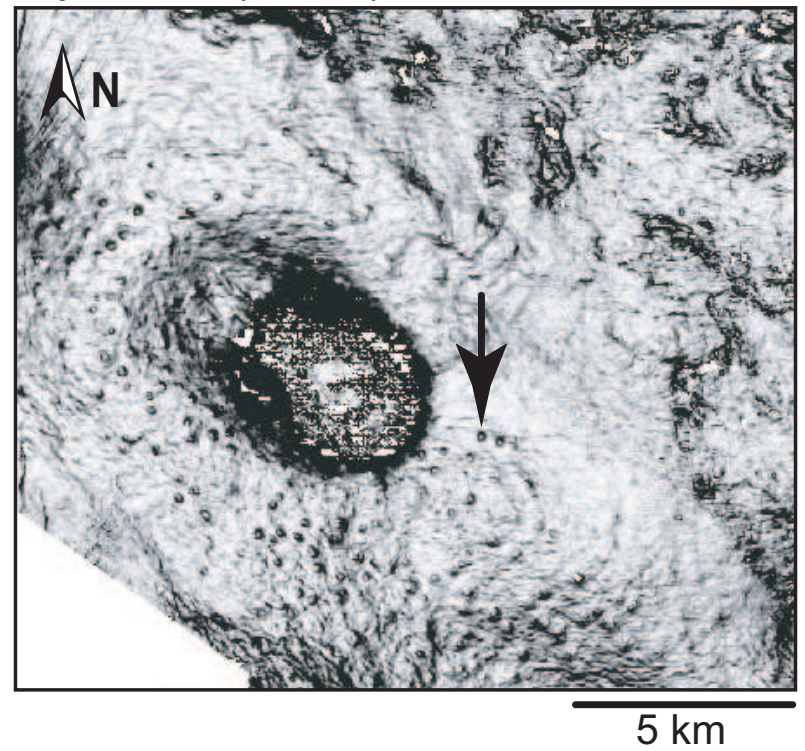

Fig. 5
Dan area (Area 3)

$5 \mathrm{~km}$

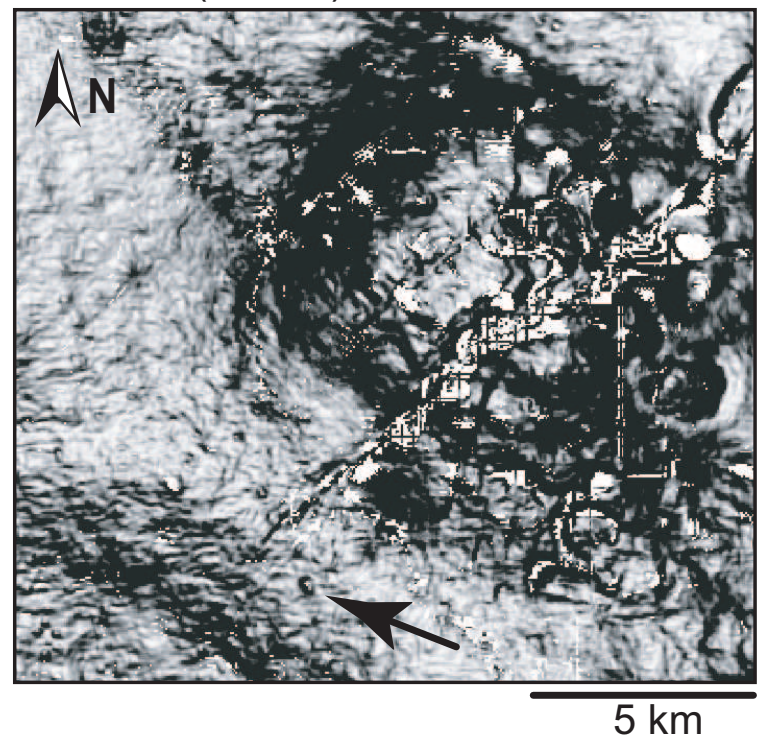




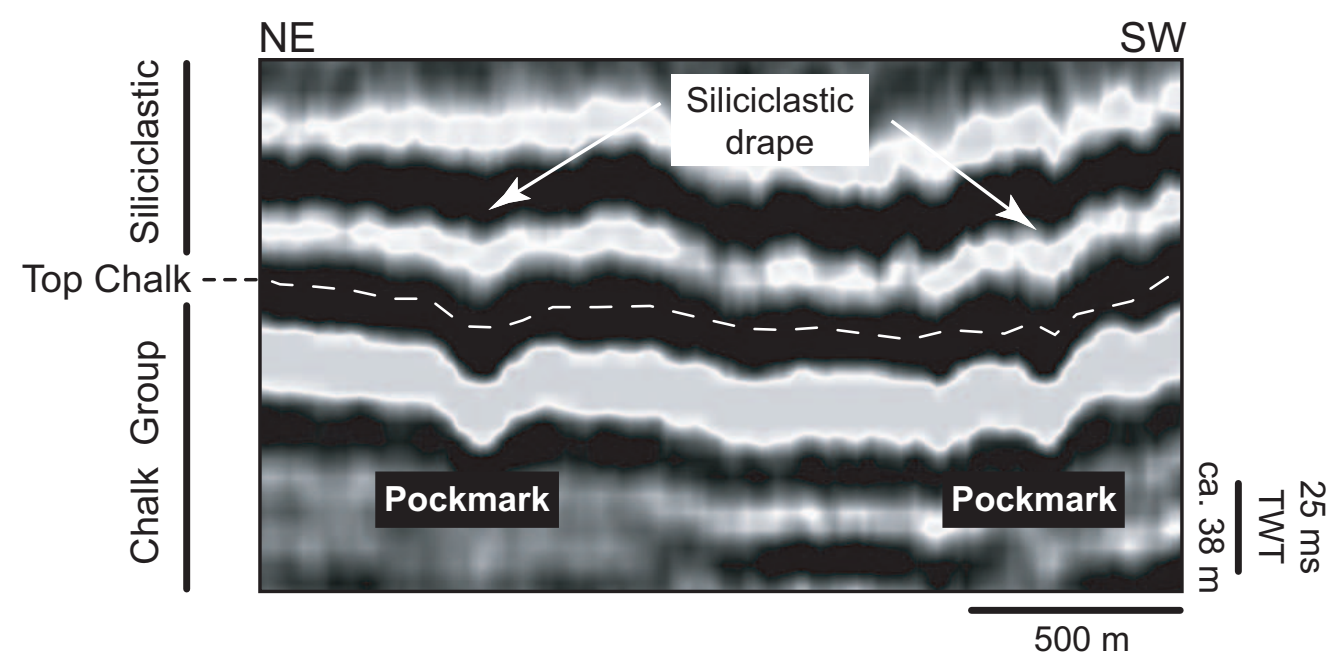

Fig. 6 

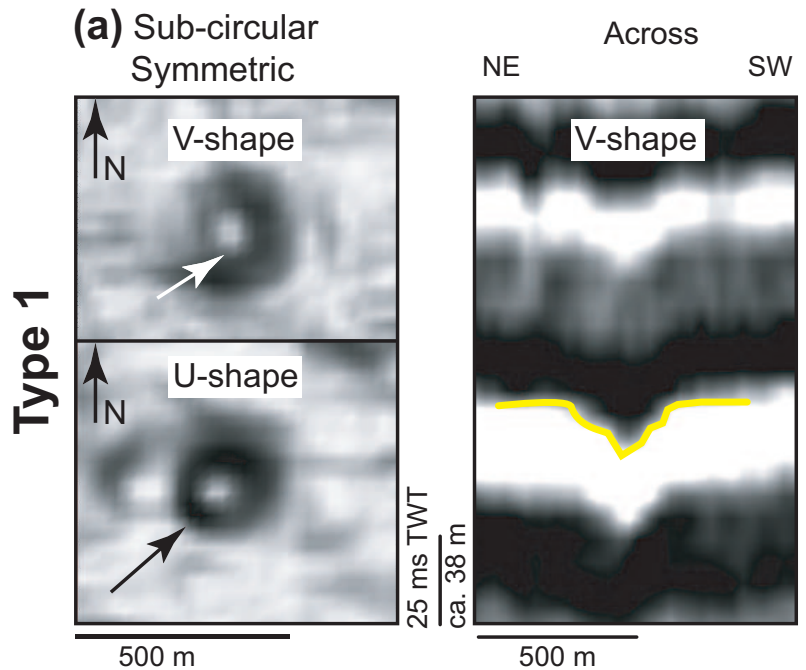

sW NW

Along

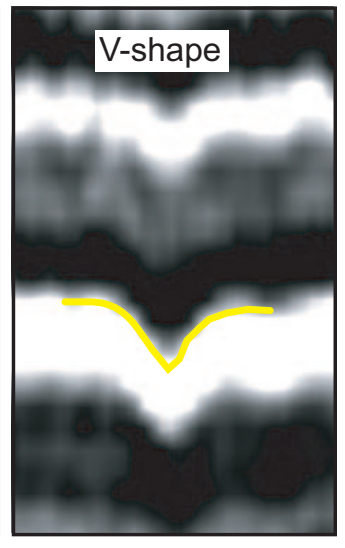

(b) Elongate

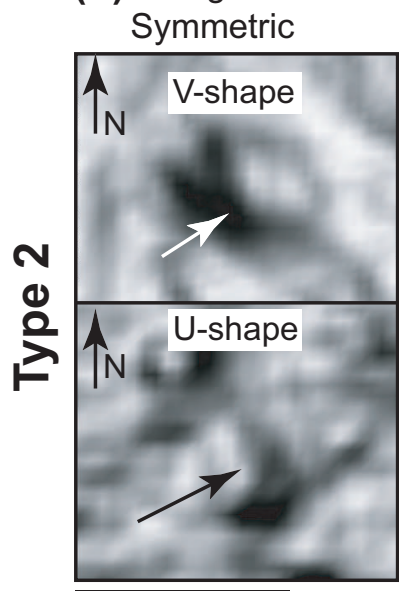

$500 \mathrm{~m}$

(c) Elongate

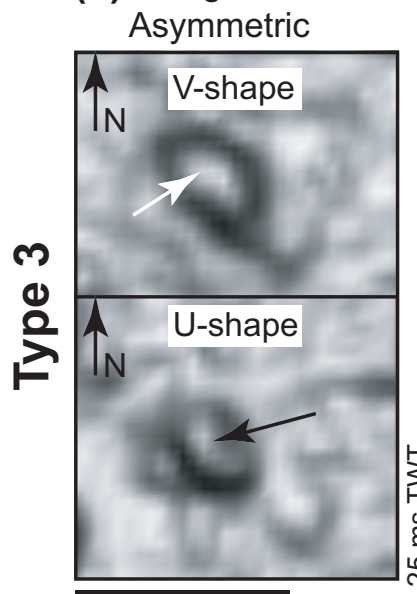

$500 \mathrm{~m}$

Fig. 7

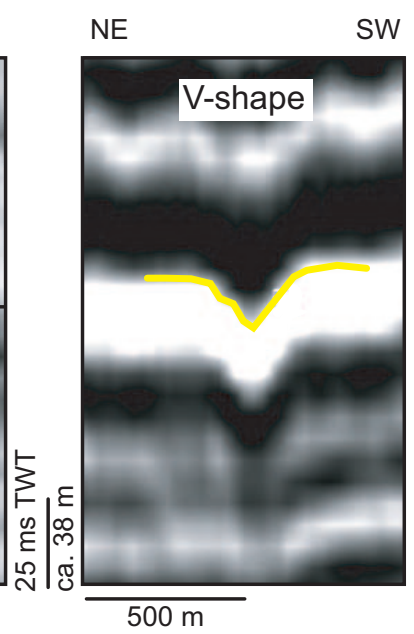

SW NW

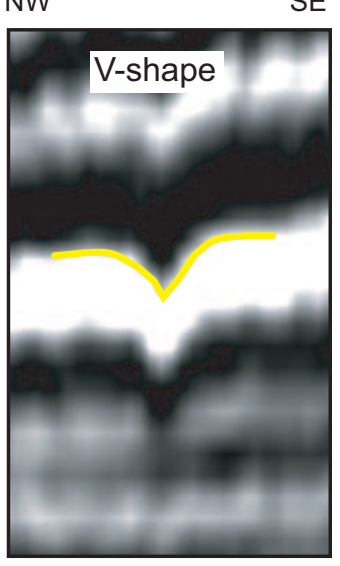

SE

NW
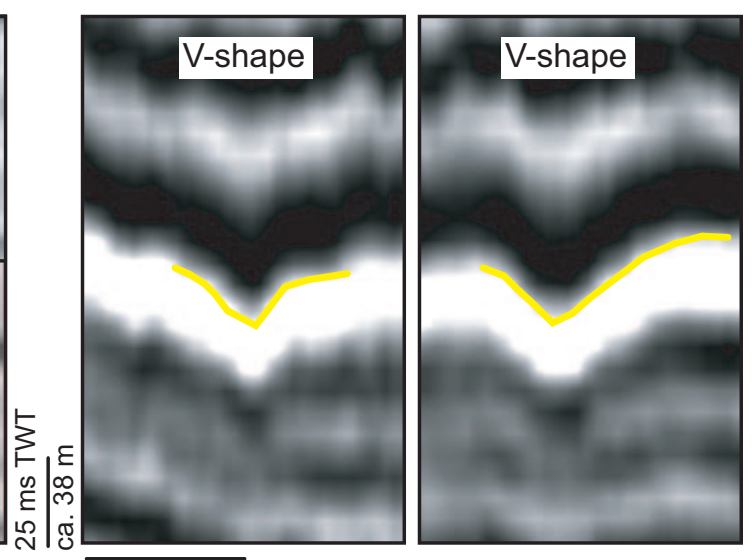

$500 \mathrm{~m}$

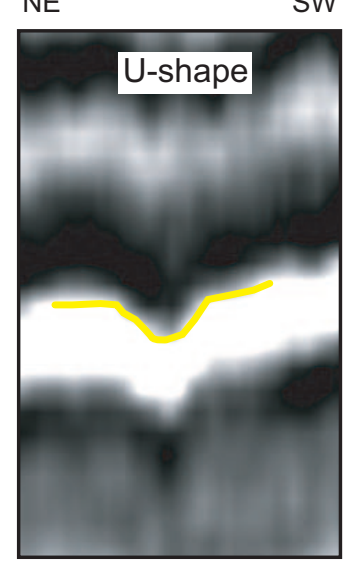

SW NW
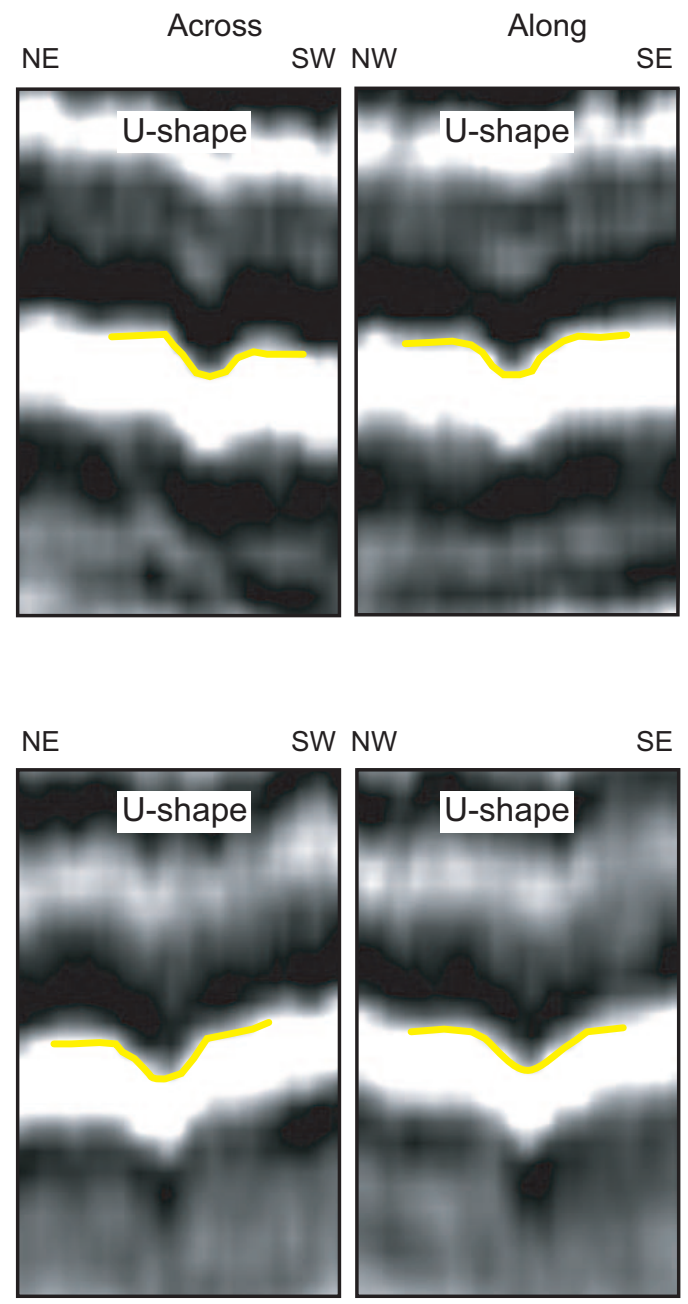

SE

E

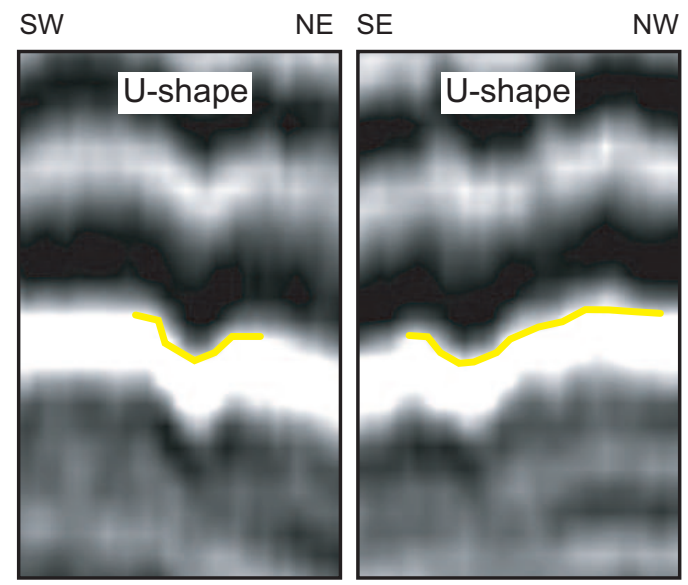

NW 


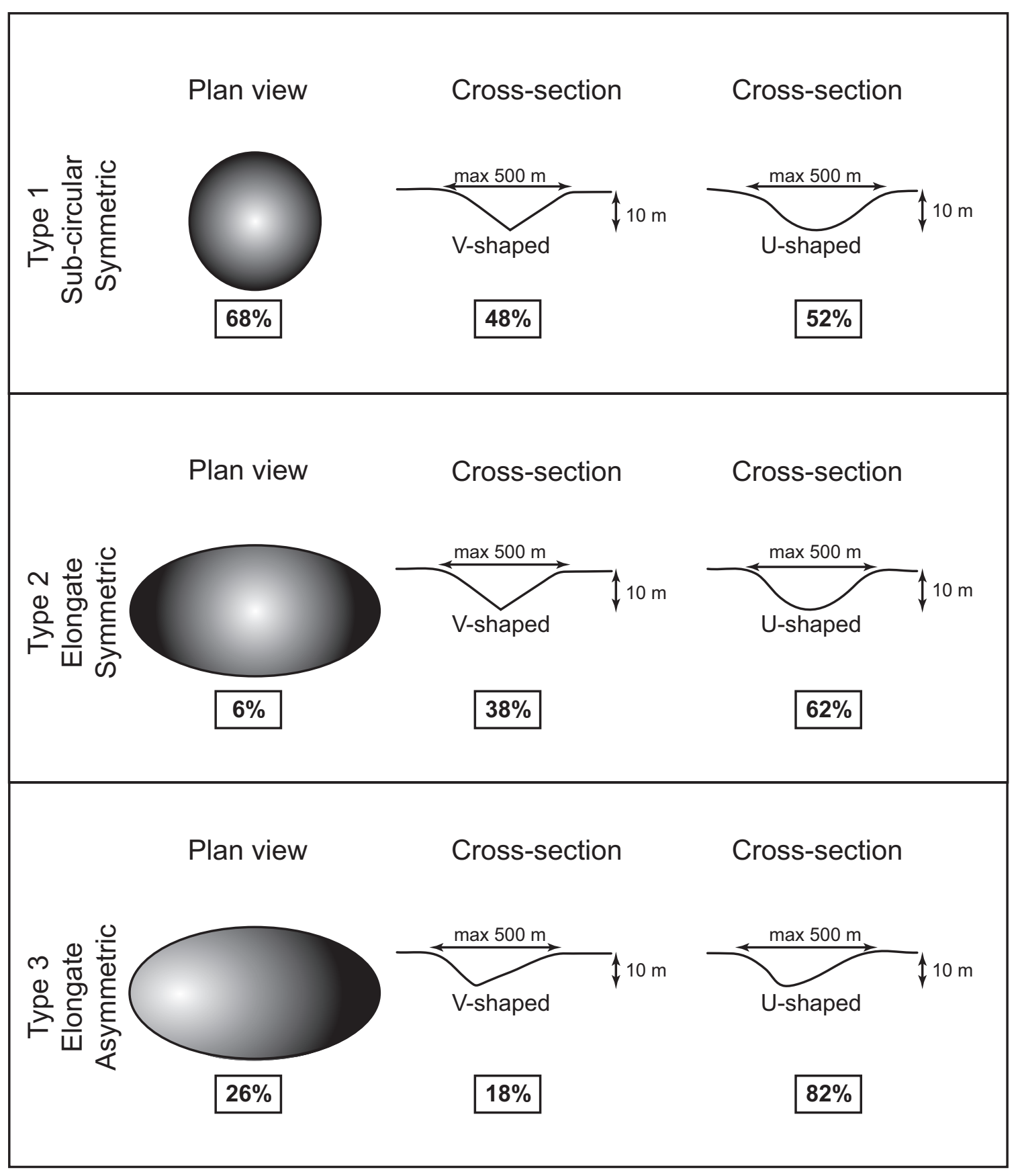

Fig. 8 

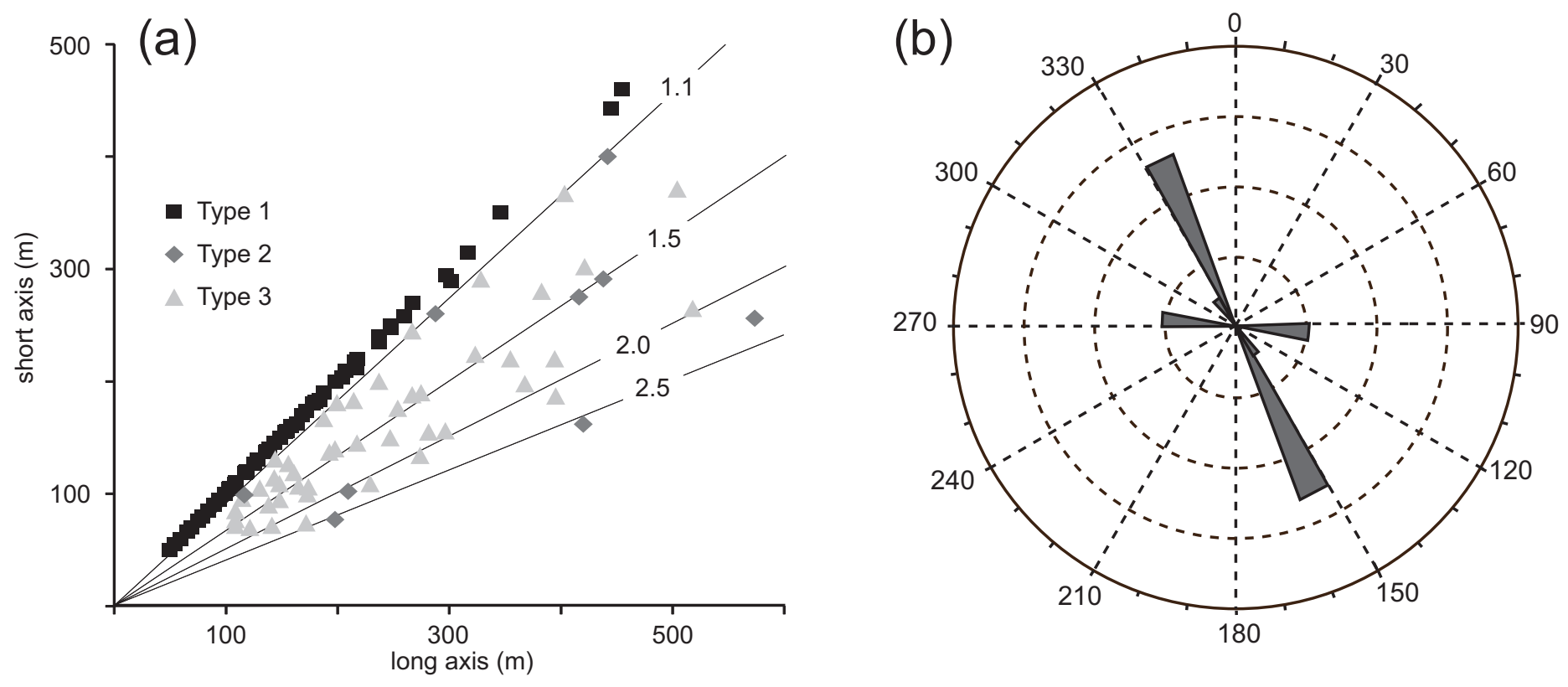

Fig. 9 
Structure Attribute, Top Chalk

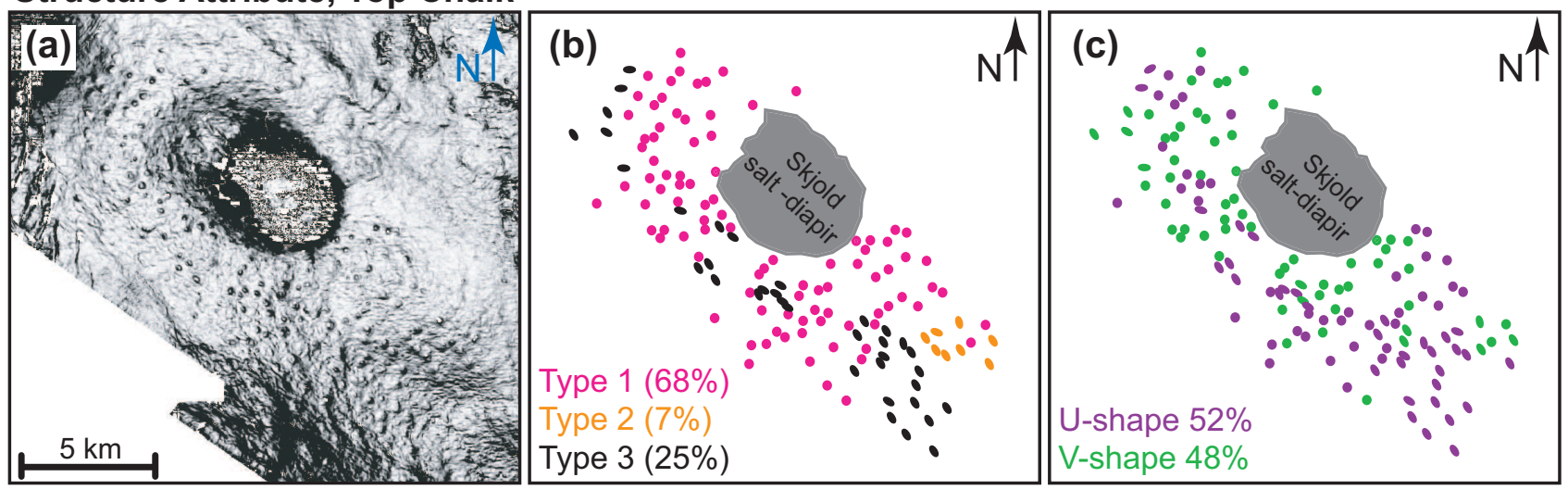

Fig. 10 
Structure Attribute
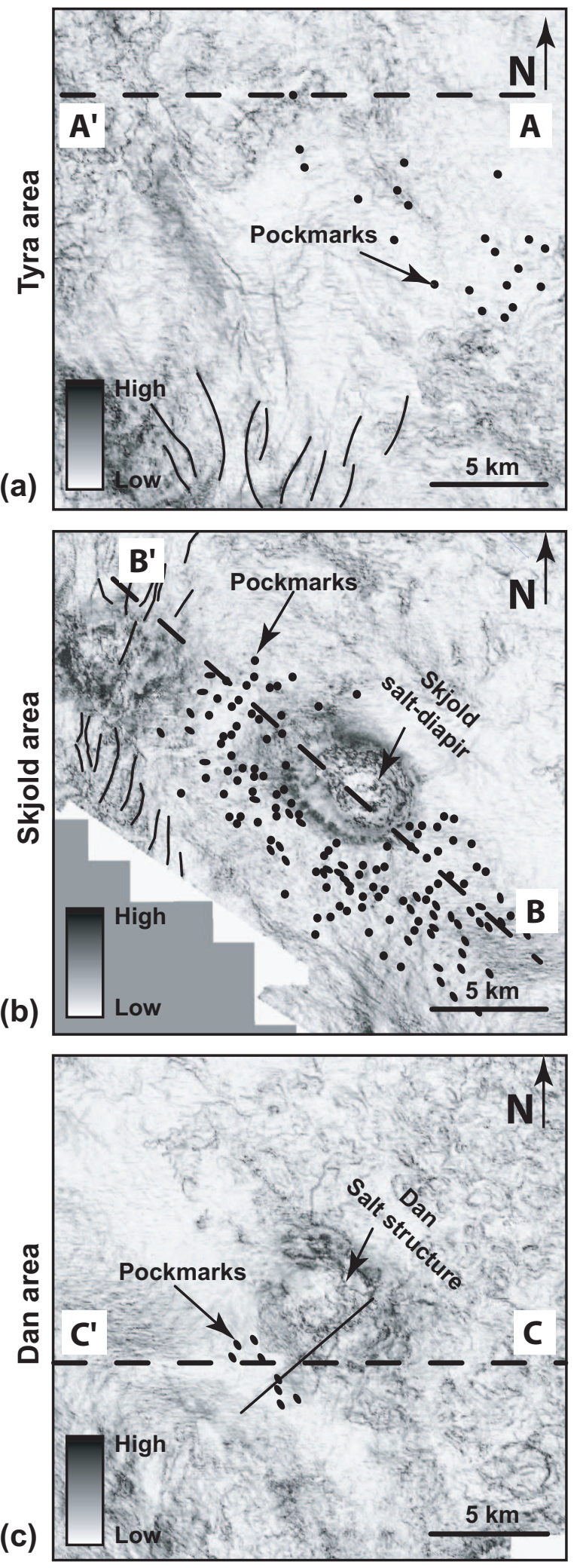

Seismic cross- section
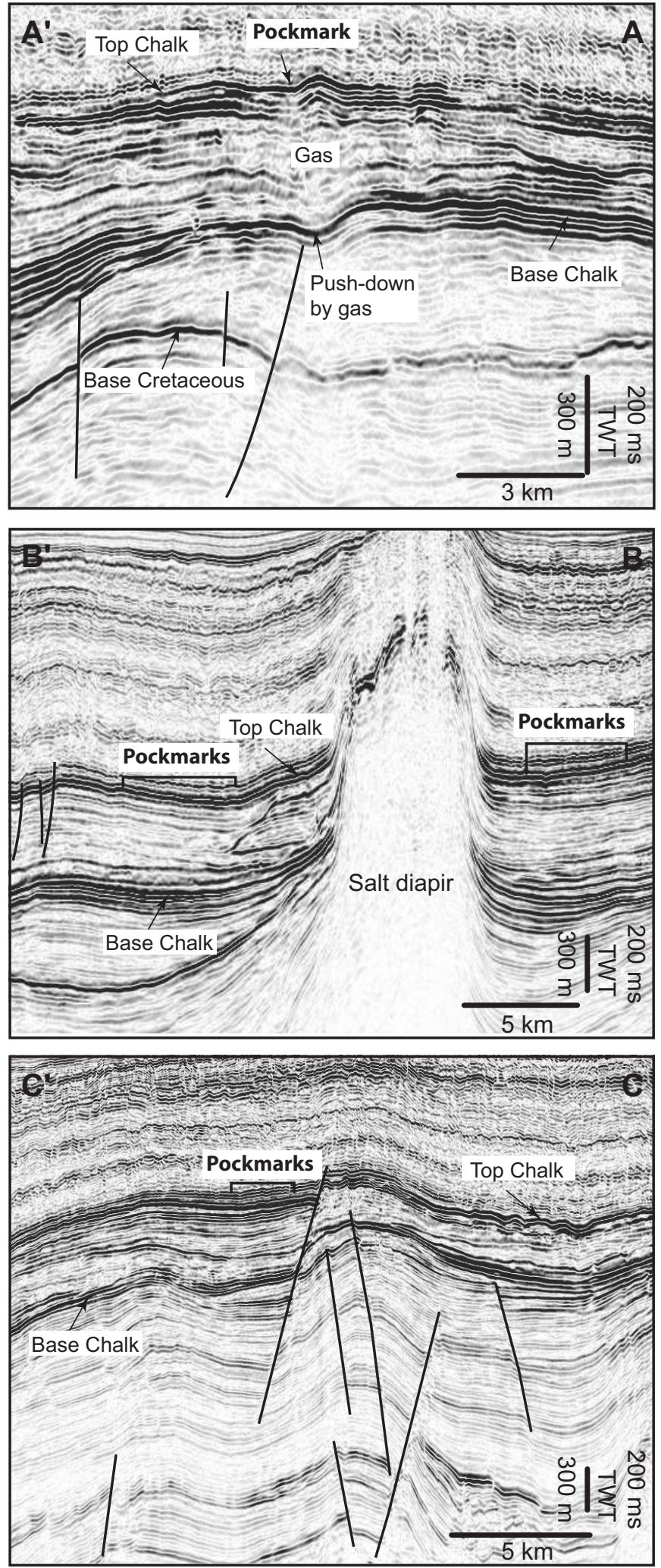

Fig. 11 


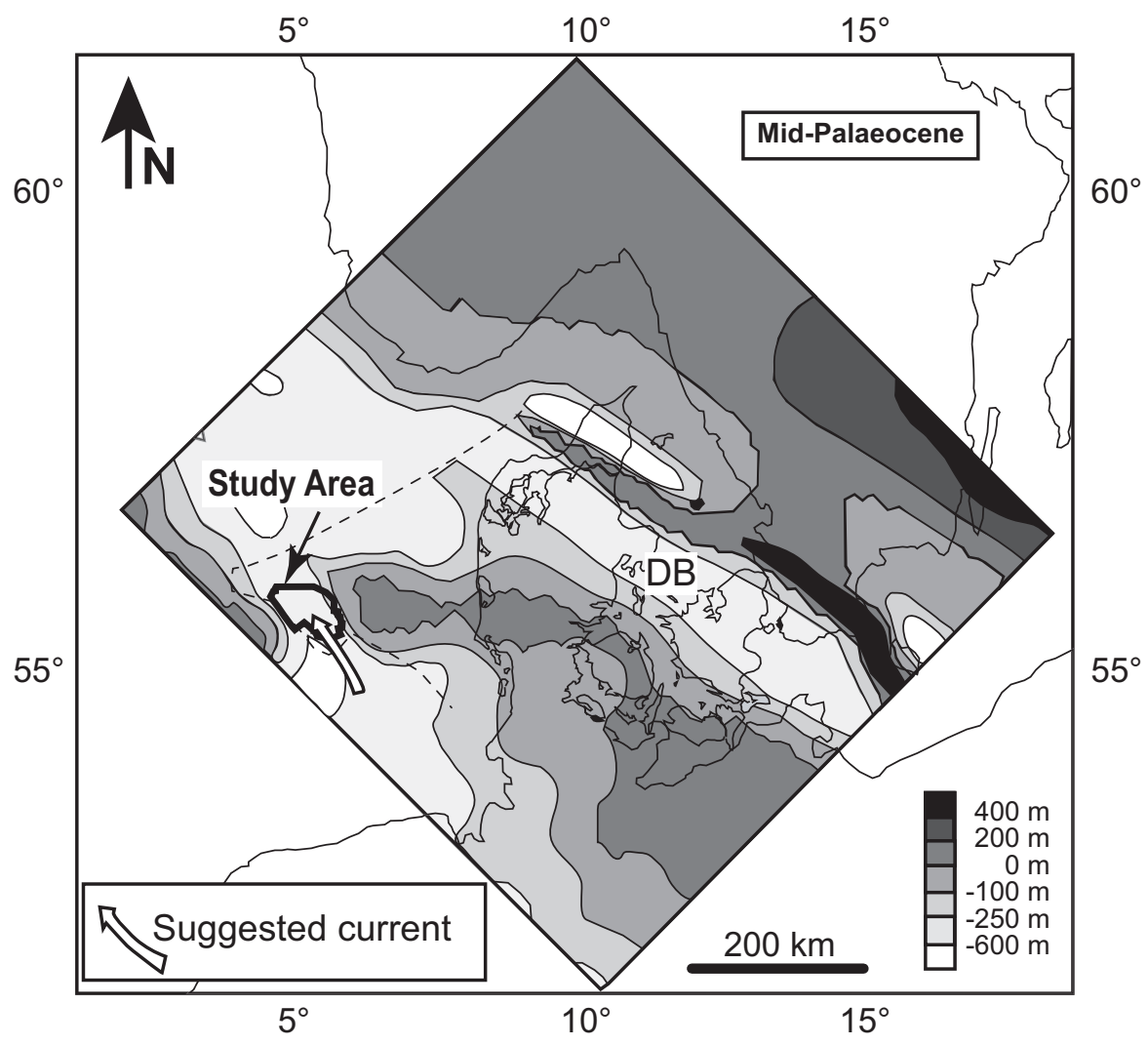

Fig. 12 


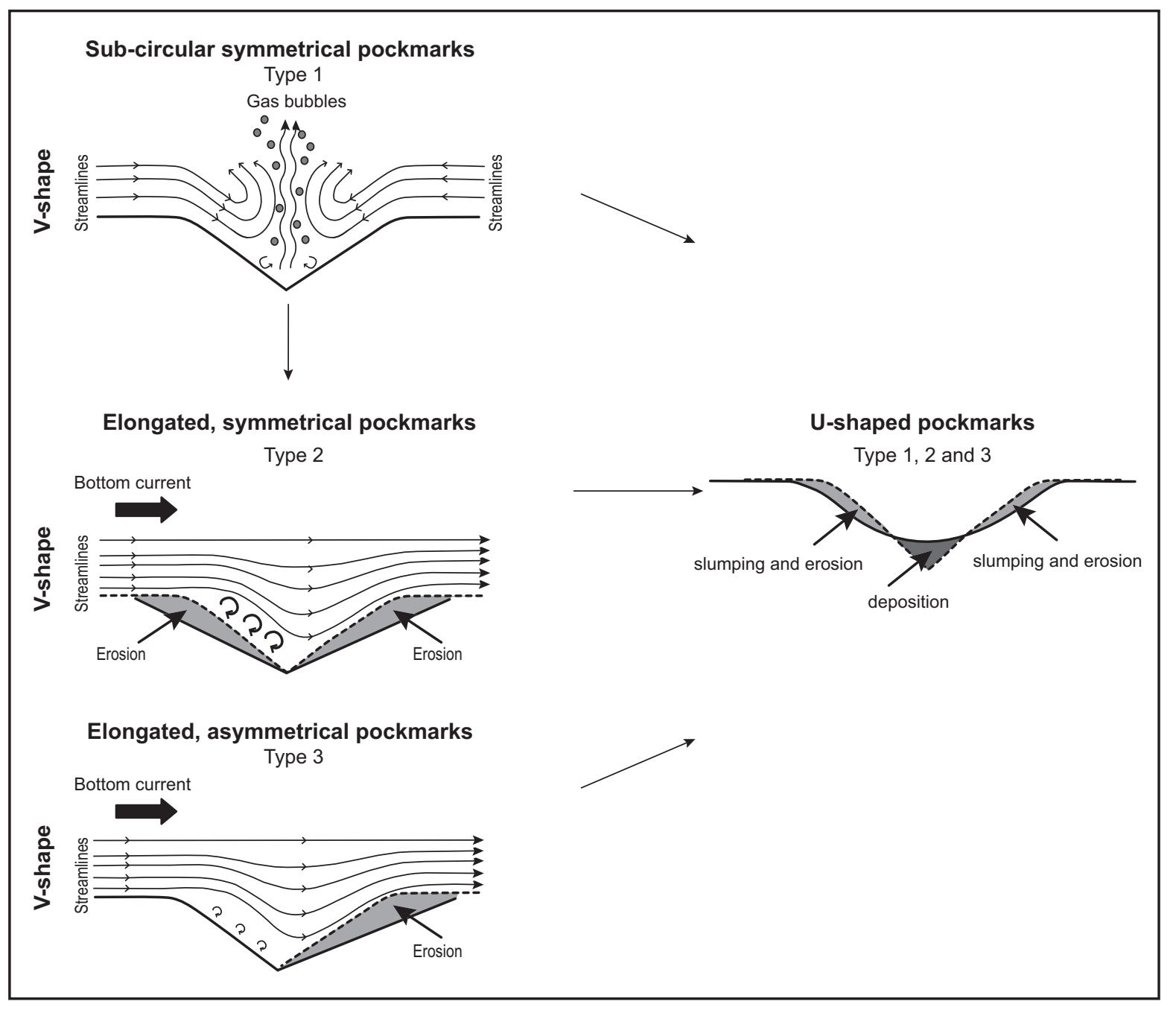

Fig. 13 